Cornell University

School of Industrial and Labor Relations

Center for Advanced Human Resource Studies
CAHRS at Cornell University 615B Ives Hall

Ithaca, NY 14853-3901 USA

Tel. 607 255-9358

www.ilr.cornell.edu/CAHRS

\title{
On the Nature and Importance of Cultural Tightness-Looseness
}

Michele J. Gelfand

Lisa H. Nishii

Jana L. Raver

Working Paper 07 - 05 


\title{
On the Nature and Importance of Cultural Tightness-Looseness
}

\author{
Michele J. Gelfand \\ University of Maryland \\ Lisa H. Nishii \\ Cornell University \\ Jana L. Raver \\ Queen's University
}

January 2007

\section{http://www.ilr.cornell.edu/cahrs}

This paper has not undergone formal review or approval of the faculty of the ILR School. It is intended to make results of Center research available to others interested in preliminary form to encourage discussion and suggestions.

Most (if not all) of the CAHRS Working Papers are available for reading at the Catherwood Library. For information on what's available link to the Cornell Library Catalog: http://catalog. library.cornell.edu if you wish. 


\begin{abstract}
Cross-cultural research is dominated by the use of values despite their mixed empirical support and their limited theoretical scope. This article expands the dominant paradigm in crosscultural research by developing a theory of cultural tightness-looseness, the strength of social norms and degree of sanctioning within societies, and advancing a multilevel research agenda for future research. Through an exploration of the top-down, bottom-up, and moderating impact that societal tightness-looseness has on individuals and organizations, as well as on variability across levels of analysis, the theory provides a new and complementary perspective to the values approach.
\end{abstract}

The article was supported by National Science Foundation Grant \#9910760.

The authors extend their gratitude to the Editor, two anonymous reviewers, and to Beng-Chong Lim, Katherine Klein, Arie Kruglanski, and Harry Triandis for their very helpful comments. Correspondence can be sent to mgelfand@psyc.umd.edu . 


\section{On the Nature and Importance of Cultural Tightness-Looseness}

Over the last two decades, research on culture has greatly increased its theoretical and empirical scope. Once a field that was largely culture blind and culture bound (Triandis, 1994), today, virtually no area of psychology has been left unaffected by the quest to understand crosscultural differences_from micro processes such as work motivation (Erez \& Earley, 1987), to meso processes such as conflict (Gelfand \& Brett, 2004), group dynamics (Earley, 1993) and leadership (House, Hanges, Javidan, Dorfman, \& Gupta, 2004), to macro processes such as human resource (HR) practices and organizational culture (Kanungo \& Jaeger, 1990). The importance of cross-cultural research cannot be underestimated, as cross-cultural research is critical to making the science of psychology universally applicable and to helping organizations manage cultural differences as they continue to globalize.

Although a cross-cultural lens has been applied to diverse phenomena, as is the case in many scientific fields, there exists a single underlying "dominant paradigm" within which research on cultural differences has proceeded. Most, if not all, research has relied upon values (cross-situational principles that guide one's life; Schwartz, 1994), to explain cultural differences. To be sure, the use of values to explain cultural differences has intuitive appeal. Values are broad constructs that psychologists have been examining for decades, and thus, their use has enabled researchers to understand the complexity of culture in familiar psychological territory (Bond, 1997). Values also lend themselves easily to measurement at the individual level, where much of the research on culture resides (Morris, Polodny, \& Ariel, 2000). Using values to understand cultural differences is also a welcome shift in a field that was once largely atheoretical and used geography as a proxy for culture. In all, values have provided much promise to the study of cultural differences.

Yet, despite their intuitive appeal, there is growing criticism that values cannot fully explain cultural differences in behavior. First, the sole reliance on values for understanding culture has 
been questioned on empirical grounds. While some studies illustrate that values are useful explanatory concepts (Morris, Williams, Leung, \& Larrick, Mendoza, et al., 1998; Smith \& Schwartz, 1997), still others show that values do not always have explanatory power in understanding cultural differences (e.g., Ip \& Bond, 1995; Leung, Bond, \& Schwartz, 1995; Tinsley, 1998). Even when the value construct is broadened to include other "person" variables, such as attitudes and beliefs, they are still mixed in their ability to explain cross-cultural differences in behavior (see Bond, 1997 for a review). Nevertheless, as Bond, Leung, Au, Tong, and Chemonges-Nielson (2004) noted, "This approach is firmly entrenched, despite the mixed empirical success of values at unpackaging cultural differences in individual responses" ( $p$. 178).

The sole reliance on values to understand cultural differences has also been questioned on theoretical grounds. Numerous scholars have argued that the extensive focus on values in cross-cultural psychology reflects a subjectivist bias where culture is reduced to factors that exist inside the individual's head (Earley \& Mosakowski, 2002; Gabrenya, 1999; Morris et al., 2000). This focus on cross-cultural differences in internal values has taken place in the absence of a concomitant focus on external influences on behavior, such as cultural norms and constraints, social networks, and components of the larger social structure, or what can be called a structuralist approach (Gabrenya, 1999; Morris et al., 2000). Akin to the long-standing debate in psychology regarding the role of personality and situations in determining behavior (Mischel, 1977), cross-cultural research has focused mainly on "person" variables, and has rarely focused on how external norms and constraints also help to explain cross-cultural differences in behavior. Put simply, a focus on internal values to the neglect of constraints of the environment leaves at least half of the "cultural picture" unexplained.

In sum, although the use of values to understand cultural differences has dominated the field, there is growing recognition that new perspectives are needed to supplement this approach. Bond (1997) remarked, "It may be judicious for us to escape the thrall of values in 
cross-cultural work and augment our conceptual toolkit" (p. 269-70). Earley and Mosakowski (2002) also urged that "now is an opportune time for researchers to move away from the tried and true friends of cultural values as the sole indicators of cultural differences" (p. 316). In much the same way, Mowday \& Sutton (1993) argued that some of the most promising work on organizations is that which focuses on the external context in general, and external constraints, in particular.

In this article, we begin to fill this void by introducing a multilevel theory of cultural tightnesslooseness, defined as the strength of social norms and degree of sanctioning within societies. Scholars from anthropology (Pelto, 1968), sociology (Boldt, 1978a, b), and psychology (Berry, $1966,1967)$ have long argued that the strength of social norms and sanctioning is an important component of the societal normative context. Triandis (1989) later discussed tightnesslooseness as a critical yet neglected dimension of cultural variation, and one that is clearly differentiated from individualism-collectivism. Yet perhaps because of the sheer focus on values, there has been almost no research attention to this dimension in modern societies, and discussions of tightness-looseness as it relates to organizations are virtually nonexistent.

Our theory of cultural tightness-looseness offers several contributions to the literature. Following recommendations for multilevel theory building (Kozlowski \& Klein, 2000), we delineate both top-down and bottom-up processes that link external societal constraints—-the strength of societal norms and sanctions— with individuals' psychological processes and organizational processes. In this way, our model provides a multilevel research agenda on how external societal constraints affect a wide range of phenomena. ${ }^{1}$ The theory also has the potential to explain cross-cultural variation in territory that has rarely been explored, including for example, the relationship between societal culture and accountability at the individual level, societal culture and organizational culture strength, alignment, and innovation at the organizational level, and societal culture and the dynamics of fit across multiple levels of analysis. Our theory also fills an important void by addressing how societal tightness-looseness 
relates to variance within societies. Culture scholars have recognized that there can be great within-societal variation (Rohner, 1984; Strauss \& Quinn, 1997), yet there is surprisingly little theory on precisely why there is marked variance within some societies and not others (Au, 1999; Schwartz \& Sagie, 2000). We argue that the linkage between tightness-looseness and variance is not only important for advancing culture theory, but also has important methodological implications for the study of culture. Before introducing our model, we discuss the nature of tightness-looseness and its divergence from other dimensions of culture.

\section{Tightness-Looseness Defined}

Societal tightness-looseness has two key components: The strength of social norms, or how clear and pervasive norms are within societies, and the strength of sanctioning, or how much tolerance there is for deviance from norms within societies. Although there is little research on this dimension in modern societies, scholars in anthropology, sociology, and psychology, discussed the importance of this dimension primarily in the 1960s and 1970s.

Pelto (1968), an anthropologist, was the first to theorize on tightness-looseness, arguing that traditional societies varied on their expression of and adherence to social norms. He identified the Pueblo Indians, Hutterites, and Japanese as examples of tight societies, in which norms were expressed very clearly and unambiguously, and severe sanctions were imposed on those who deviated from norms. By contrast, he identified the Skolt Lapps of Northern Finland and the Thais as loose societies, in which norms were expressed through a wide variety of alternative channels, and where there was a general lack of formality, order, and discipline, and a high tolerance for deviant behavior. Pelto (1968) also identified a number of antecedents to tightness-looseness, including population density, kinship systems, and economic systems. For example, he argued that societies that have unilineal kinship systems (i.e., descent is traced to either the male or the female) tend to be tight whereas societies that have bilateral kinship systems (i.e., descent is traced to both males and females) tend to be loose. He also argued that agricultural societies are tighter than hunting and gathering societies, given that the former 
require rigid norms to foster the coordination necessary to produce crops for survival. Within sociology, Boldt and his colleagues later supported this notion, showing that agricultural societies have clearly defined role expectations that leave little room for improvisation, whereas hunting and fishing societies have ambiguous role expectations that enable individuals to exercise their own preferences (Boldt, 1978a, 1978b; Boldt \& Roberts, 1979).

In psychology, Berry $(1966 ; 1967)$ showed that individuals in tightly-structured agricultural settings (e.g., the Temne of Sierra Leone) exhibited lower psychological differentiation (i.e., a reduced sense of separation of the self from others, Witkin \& Berry, 1975), as compared to individuals in loosely-structured hunting and fishing settings (e.g., Eskimos). Similarly, Dawson (1967a, 1967b) found that in groups that had strict discipline (e.g., the Temne), children were more likely to develop a field dependent cognitive style as compared to groups which have more lenient childrearing practices (e.g., the Mende of Sierra Leone).

After a general hiatus of research on the topic, Triandis reintroduced the dimension of tightness-looseness in 1989, and argued that it is an important yet neglected dimension of culture that is distinct from individualism-collectivism. Carpenter (2000) supported this supposition in a study of ethnographies of 16 traditional societies in the Human Relations Area Files. She found that individualism-collectivism and tightness-looseness were only moderately correlated $(r=.44)$.

In sum, early research in anthropology, sociology, and psychology showed the promise of tightness-looseness for understanding cultural differences. Across multiple disciplines, scholars demonstrated the importance of examining cultural differences in external constraints—the strength of external norms and sanctioning - a perspective that was not being tapped by the more common values approach. Nonetheless, scholarship on the topic has generally been at a standstill, and there has been almost no theorizing or research on tightness-looseness in modern societies or on organizations and individuals therein. In this article, we seek to begin filling this void by advancing a multilevel theory of tightness-looseness in modern societies. 


\section{Tightness-Looseness: Divergent Validity}

Before turning to our theory, it is worth noting what tightness-looseness is not, or in other words, how it diverges from other dimensions of culture. Tightness-looseness (TL) is not individualism-collectivism (IC) (Carpenter, 2000; Chan, Gelfand, Triandis, \& Tzeng, 1996; Triandis, 1989). IC refers to the degree to which societies emphasize having strong ties to ingroups versus being autonomous and looking after oneself (Hofstede, 1980), and it does not refer to how pervasive social norms are or to how much tolerance there is for deviance from norms within societies. There are societies or groups that are generally collectivistic and loose (e.g., Brazil, Hong Kong), collectivistic and tight (e.g., Japan, Singapore), individualistic and loose (e.g., the U.S., New Zealand), and individualistic and tight (e.g., Germany) (cf. Chan et al., 1996; Triandis, 1989). As noted above, the differentiation of tightness-looseness and individualism-collectivism has also received empirical support in traditional societies (Carpenter, 2000). Tightness-looseness is also distinct from uncertainty avoidance (UAI), or the level of stress that is experienced in a society in the face of an unknown future (Hofstede, 1980). Although tight societies may be higher on uncertainty avoidance, it is also possible that the converse is true. Tight societies have many clear norms, and thus, stress deriving from uncertainty may effectively be eliminated among its citizens. For example, as we discuss below, Singapore is expected to be generally tight, yet it ranked the lowest on Hofstede's (1980) index of uncertainty avoidance. Finally, tightness-looseness is distinct from power distance (PD), or the extent to which power is distributed equally in societies (Hofstede, 1980). Conceptually, strong norms and sanctioning can be reinforced and sustained in cultures that have a high degree of inequality (high power distance), as well as in cultures that have a high degree of equality (low power distance), and thus, there should be a low correlation between the constructs.

In sum, tightness-looseness captures unique cultural variance and is distinct from other cultural dimensions. Put simply, each of these dimensions explains "different" cultural variance. 
IC relates to how behavior is influenced by one's ingroup and/or family; PD relates to how behavior is influenced by authorities; UAI relates to how behavior is influenced by stress and uncertainty; and TL relates to how behavior is influenced by the strength of social norms and sanctioning. In all, TL is unique and complementary to other cultural dimensions.

In this article, we focus on societal variation in tightness-looseness and propose that modern societies vary considerably in their strength of norms and sanctioning. However, we also emphasize that that there is likely variability within societies on tightness-looseness, either across domains of life (e.g., Chan et al. 1996), regions (e.g. the North and South of the U.S.), or ethnic and religious groups (e.g., the Taliban), a point to which we will return in the discussion.

Proposition 1a: Tightness-looseness consists of the strength of social norms (number and clarity) and the strength of sanctioning (tolerance for deviance from norms).

Proposition 1b: Tightness-looseness is distinct from collectivism, uncertainty avoidance, and power distance. There is societal variation in tightness-looseness as well as withinsocietal variation in tightness-looseness (e.g., by region, ethnic group, domains of life).

Research Implications of Propositions 1a and 1b. The previous discussion highlights the need to develop measures of tightness and looseness for cross-cultural research in modern societies. There are numerous measures of cultural values and beliefs, which reflects their theoretical and empirical dominance in the field, and comparatively, a dearth of measures of cultural norms. Consistent with other culture-level research (Hofstede, 1980; House et al., 2004; Schwartz, 1994), it will be important to develop and validate scales which assess the strength of norms and sanctions across cultures. ${ }^{2}$ Tightness-looseness can also be assessed through measures derived from Jackson's (1966) Return Potential Model. For example, although it has yet to be applied to the societal level, Jackson's (1966) measure of the range of tolerable behavior is directly linked to our notion of the latitude of social norms. Measures of situational constraint (Price \& Bouffard, 1974), which examine how appropriate a wide range of behaviors are across a wide range of situations, can also be used in studies of tightness-looseness. Qualitative research, which examines public symbols, including popular heroes, proverbs, 
literature, music, art, and fashion, can also be used to examine variations in societal tightnesslooseness. For example, popular books, heroes, and proverbs are likely to reflect an emphasis on abiding by norms in tight societies versus tolerance for deviance in loose societies (e.g., in the U.S., First, Break all the Rules, Buckingham \& Cuffman, 1999).

\section{A Multilevel Model of Societal Tightness-Looseness}

With tightness-looseness defined and differentiated from other constructs, we now turn to our multilevel model of societal tightness-looseness. In what follows, we discuss top-down, bottom-up, and moderating influences of societal tightness-looseness on organizations and individuals. We first discuss cross-level linkages that relate societal tightness-looseness and individual level characteristics and behavior, as well as variance across individuals (Propositions $2 a-3 b)$. We then discuss cross-level linkages that relate societal tightness-looseness to organizational practices and culture strength (Propositions 4a-c), and bottom-up processes through which individual level characteristics reinforce organizational practices and culture strength (Propositions 5a-b). We discuss other contextual antecedents of tightness-looseness in organizations (Propositions 6a-b), as well as key outcomes associated with tightness-looseness at the organizational level (Proposition 7). We conclude with a discussion of the deleterious consequences of "misfit" across levels of analysis, particularly in tight societies (Propositions 810). After clusters of propositions, we discuss specific research implications and measurement strategies that can be used to test the propositions. 
Figure 1

\section{A Multilevel Model of Tightness-Looseness}

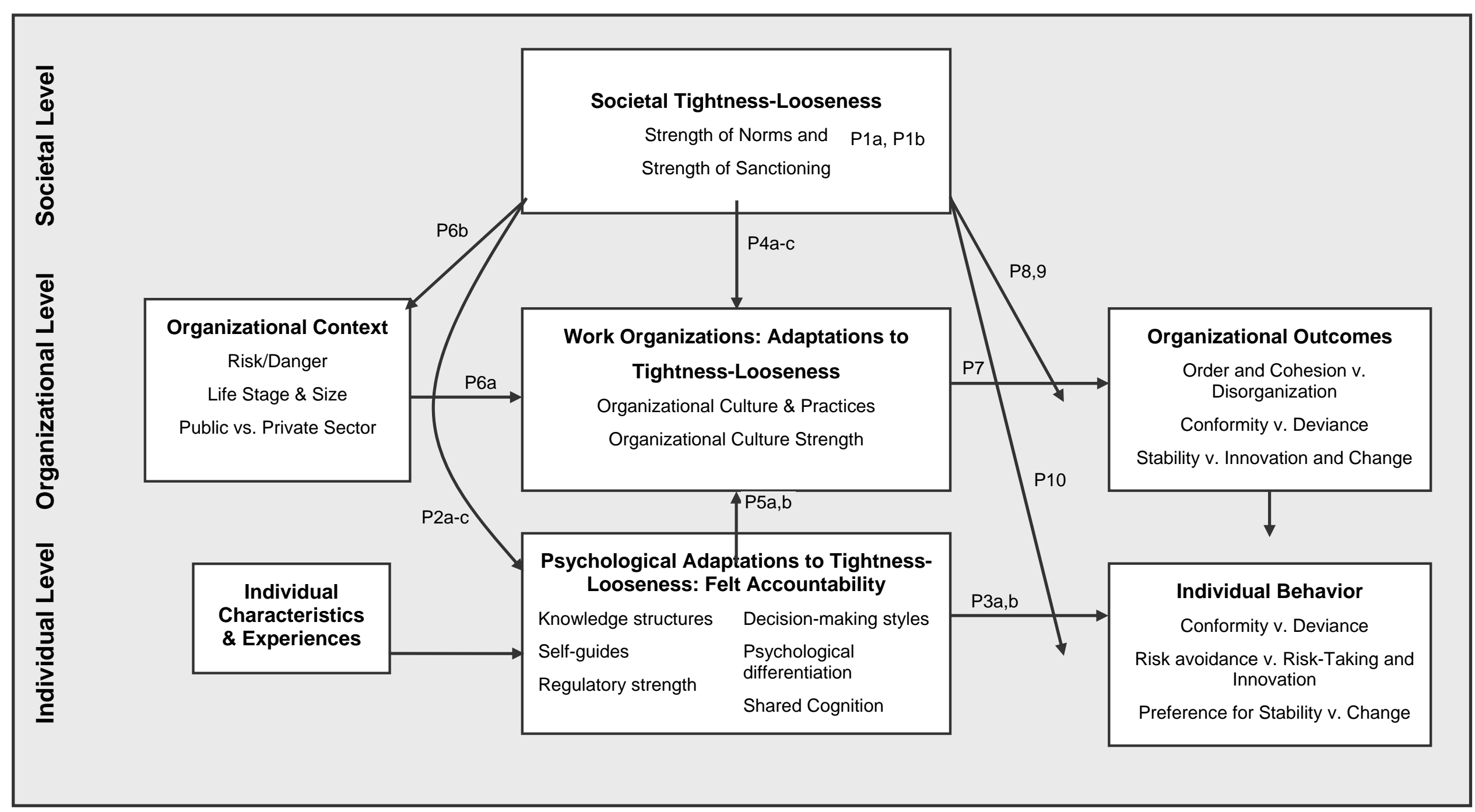


Several overarching meta-theoretical themes will become evident in the discussion of the model. First, a central issue that differentiates tight and loose societies is the amount of accountability (Tetlock 1985, 2002) that exists at the societal and organizational levels, and the degree of "felt accountability" (Frink \& Klimoski, 1998) that exists at the individual level. To our knowledge, the model is one of the first to systematically integrate theory and research on accountability with culture. Additionally, felt accountability is a new psychological mechanism advanced to understand how external societal constraints are internalized and influence behavior. Second, tightness-looseness is related to the degree of variance at multiple levels in societies. We advance that the strength of norms and monitoring in tight societies reduces the range of variation at multiple levels of analysis, generally evidencing itself in higher socially shared cognition and similarity in behavior among individuals, higher culture strength and alignment in organizations, and greater institutional pressures, and thus similarity across organizations, as compared to loose societies. Third, tightness-looseness is posited to have quasi-isomorophic effects across levels of analysis. Key outcomes associated with tightness include order and efficiency, conformity, and low rates of change. Key outcomes associated with looseness include social disorganization, deviance, and innovation and openness to change. Finally, a key theme pervading the model is the notion of adaptation: organizations adapting to the society, and individuals adapting to societies and organizations. We also discuss the negative effects that occur when there is a lack of adaptation or "fit" in the system, particularly in tight societies.

\section{Cross-Level Effects of Societal Tightness-Looseness and Psychological Attributes:}

\section{Means and Variance}

Individuals in tight and loose societies are socialized within societal institutions that affect "the range and focus of personal variation that is acceptable and rewarded" (Scarr, 1993, p. 1337). We propose that societal institutions in tight societies promote narrow socialization (Arnett, 1995), in that they have more constraint and highly developed systems of monitoring 
and sanctioning behavior. In contrast, societal institutions in loose societies promote broad socialization (Arnett, 1995), in that they have lower constraint and weakly developed systems of monitoring and sanctioning behavior. Put simply, individuals in tight societies experience a much greater degree of normative restrictiveness across societal institutions as compared to individuals in loose societies. As we argue below, this, in turn, affects variations in the psychology of felt accountability at the individual level, and a number of derivative cognitions, self-definitions, and personal characteristics, as well as the degree of socially shared cognition within societies.

Broad versus narrow socialization. Families and teachers are the first to inculcate broad versus narrow socialization in loose and tight societies, respectively. In tight societies, parents emphasize rule abidance, monitor their children's behavior, and have stricter socialization tactics (Halloway, 1999; Ho, 1981; Pearson, 1984). A "good child" is one who abides by rules (e.g., sunao in Japan, Li-chiao, in China; Ruiz \& Tanaka, 2001). Parents in loose societies encourage more exploration among children and impose punishments that are more lenient. American mothers, for example, are much more permissive than Chinese (Chiu, 1987; Ryback, Sanders, Lorentz, \& Koestenblatt, 1980), Korean (Hupp, Lam, \& Jaeger, 1992), and Japanese mothers (Zahn-Waxler, Friedman, Cole, Mizuta, \& Hirumaa, 1996). Educational institutions also reinforce broad versus narrow socialization in tight versus loose societies. In Japanese classrooms, for example, teachers demand strict obedience from students, carefully monitor their behavior, and provide detailed reports to parents (Holzer, 2000; Stevenson \& Stigler, 1992). Monitoring of behavior need not come only from teachers in tight societies. In Syria, children are expected to inform their parents about teachers or others who may be deviating from government mandates (Hopwood, 1988). Children in China engage in reciprocal peer monitoring to make sure that their peers behave appropriately (Chen, 2000). Thus, rules and monitoring of behavior are much more pervasive in childrearing and educational practices in tight versus loose societies. 
Broad versus narrow socialization is also reinforced in loose and tight societies through the media and criminal justice systems. Media in loose societies (e.g., the U.S., New Zealand) foster broad socialization by being open and diverse in their content and by being subject to few regulations, political pressures, and controls on what is acceptable (Sussman \& Karlekar, 2002). By contrast, media in tight societies (e.g., Singapore, Saudi Arabia) foster narrow socialization by being more restricted and regulated in their content (Sussman \& Karlekar, 2002). The nature of criminal justice systems also reinforces broad versus narrow socialization across societies. In tight societies, there are a wider range of offenses that are punishable (e.g., importing chewing gum and failing to flush toilets in Singapore; Parkes, 2001; Soltani, 2003), and a greater likelihood of punishing offenders for crimes committed (United Nations Office on Drugs and Crime, 2004). Tight societies also impose stricter sanctions for crimes as compared to loose societies (e.g., amputation of feet and caning in Iran and Saudi Arabia; death penalty for drug offenses in Singapore; Amnesty International, 2002; 2004). In sum, individuals are socialized in a variety of societal institutions, and these institutions differ in the degree to which they promote narrow versus broad socialization in tight versus loose societies, respectively.

Proposition 2a: Societal institutions in tight societies generally foster narrow socialization whereas societal institutions in loose societies generally foster broad socialization.

Research Implications of Proposition 2a. Proposition 2a reflects the importance of examining the nature of societal institutions across cultures. Cross-cultural research has increasingly become reductionist, focusing mainly on culture "inside the head" of individuals (Aycan, 2000; Gabreyna, 1999; Morris et al, 2000). The study of societal institutions is often seen as a priority among sociologists, political scientists, and economists (Parboteeah \& Cullen, 2003), yet future research would benefit from integrating these macro perspectives with the micro focus typically favored by cross-cultural psychologists. A key challenge for culture scholars is to propose and validate dimensions of societal institutions and link these to dimensions of culture. Proposition 2a highlights one such dimension of societal institutions, namely broad versus narrow socialization, which applies to the media, criminal justice systems, 
education, etc., and which is conceptually linked to societal tightness-looseness. Archival databases can be used to infer the degree of broad versus narrow socialization within societies (e.g., openness of the media, penalties or crimes; Amnesty International, 2002;

Freedomhouse.org). Attitudes of parents and teachers regarding broad versus narrow socialization can also be examined through surveys, interviews, and observations. Clearly, our discussion of societal institutions is not exhaustive. Future research would benefit from examining broad versus narrow socialization in other institutions as well. Next, we discuss cross-level effects that societal tightness-looseness has on the types of psychological attributes cultivated and the range of variation across individuals (cf. Scarr, 1993).

Psychological adaptations: Felt accountability. At the individual level, we propose that societal tightness-looseness has cross-level effects on a psychological syndrome of felt accountability. Felt accountability is the subjective experience that one's actions will be subject to evaluation and that there are potential punishments based on these evaluations (Frink \& Klimoski, 1998, 2004; Tetlock, 1985). Although individuals in all societies experience some degree of felt accountability to external standards, we propose that accountability is subjectively experienced and "felt" to a much greater degree in tight than loose societies. Individuals in tight societies inhabit a social world where they feel a heightened scrutiny of their actions, and expect that violations of norms will be met with stronger punishments as compared to individuals in loose societies. In our model, felt accountability is a psychological syndrome that has a number of derivative cognitions, self-definitions, and personal characteristics, which are discussed in turn below. Importantly, felt accountability is advanced as a psychological mechanism through which external societal constraints ultimately influences behavior (Propositions 3a, 3b).

Knowledge structures. In tight societies wherein there are strong norms and sanctioning, individuals must have an extremely "reliable mental compass" (Tetlock, 2002) regarding normative expectations. We propose that individuals in tight societies will have higher cognitive accessibility of normative requirements as compared to individuals in loose societies. Research 
in social psychology by Aarts and colleagues has indeed illustrated that norms are cognitively represented in memory as associations between normative behaviors and situations. Aarts and Dijksterhuis (2003) found that there are individual differences in normative associative strength (i.e., strength of the association between situations and normative behavior), which are due to differences in social backgrounds where links between situations and norms are more or less emphasized. Normative associative strength is expected to be higher in tight than loose societies given the narrow socialization across societal institutions that dictate expected behaviors.

Self-guides. The nature of the self is posited to vary across tight and loose societies. Ideal self-guides indicate what a person hopes or aspires to be, whereas ought self-guides indicate what a person believes is his or her responsibility to be, based either on prescriptions from close others or prescriptions from the generalized society, the latter of which is referred to as "normative ought-guides" (Higgins, 1996). Higgins, Shah, and Friedman (1997) showed that there are individual differences in the accessibility of ideal and ought self-guides. We predict that individuals in tight societies, who have higher felt accountability, will tend to have chronic accessibility of normative ought self-guides and a prevention regulatory focus (i.e., will be focused on not making mistakes). Scholarship on Singapore provides indirect support of this notion. For example, the phenomenon of Kiasu, in which the "the emphasis is on not losing rather than winning or on reducing risk of failure, rather than striving for success" (Wu \& Dai, 2001, p.10; see also Ramakrishnan, 1998), reflects the prevention focus that is pervasive in Singapore. By contrast, individuals in loose societies, who have lower felt accountability, will tend to have chronic accessibility of ideal self-guides and will have more of a promotion focus (i.e., will be focused on achieving goals or targets).

Regulatory strength. Individuals in all societies monitor and evaluate their behavior to detect discrepancies from standards, and have negative self-reactions when such discrepancies occur (Bandura, 1982; Carver \& Scheier, 1981; Kanfer, 1990). However, there are individual 
differences in these processes, collectively known as regulatory strength (Baumeister \& Heatherton, 1996). We extend this theory by proposing that individuals in tight societies generally have higher self-regulatory strength than individuals in loose societies. Individuals in tight societies, who have higher felt accountability, engage in more frequent monitoring of their behavior vis-à-vis social norms, are more attentive to discrepancies from norms, and have more intense negative self-reactions when their behavior errs from standards, as compared to individuals in loose societies. Put simply, the high (low) degree of social regulation at the societal level is mirrored in the high (low) amount of self-regulation at the individual level in tight and loose societies, respectively. This is consistent with Seeley and Gardner (2003) who found that Caucasians have lower self-regulatory strength as compared to Asians.

We expect that individuals in tight societies are not only attentive to their own behavior vis-àvis external standards, but also have an enhanced attentiveness and negative reactions to others' violations, as compared to individuals in loose societies. Tetlock (2002) referred to this psychological mindset as one of an "intuitive prosecutor" who is concerned with upholding the social order, is acutely attuned to notice norm violations, and is motivated to sanction others (Rucker, Polifroni, Tetlock, \& Scott, 2004). Because maintaining social order is important in tight societies, individuals will have an intuitive prosecutor mind-set more cognitively accessible. By contrast, in loose societies, deviance by others is less likely to be noticed, and even when it is noticed, it will be much more tolerated. This is consistent with Gelfand, Nishii, Chan, Yamaguchi, \& Triandis (1998), who found that Japanese had more negative reactions to norm violations, and were more supportive of sanctioning violators, as compared to Americans.

Decision-making styles. Societal tightness-looseness is expected to relate to preferred ways of gathering, processing, and evaluating information when solving problems, and to adaptor and innovator cognitive styles (Kirton, 1976), in particular. Adaptors prefer to derive ideas for solutions to problems by using established procedures, and have been characterized as being cautious, reliable, efficient, and disciplined (Kirton, 1976; Kirton \& Baily, 1991). We 
expect this style to be generally preferred in tight societies, where there is high felt accountability to external standards and expectations of punishment for deviations. By contrast, innovators prefer to challenge established rules and procedures, ignore constraints of prevailing paradigms, and derive their ideas for solutions from outside of the system (Kirton \& Baily, 1991). Innovators have been characterized as being original and risk-seeking, yet also as undisciplined, impractical, and disrespectful of customs (Kirton \& Baily, 1991). We expect this style to be generally preferred in loose societies, where there is less felt accountability to standards and threat of punishment for deviations. More formally, we predict:

Proposition 2b: Societal tightness-looseness has cross-level effects on felt accountability at the individual level. Individuals in tight versus loose societies will generally have higher (lower) accessibility of normative requirements, a greater prevention (promotion) focus, higher (lower) regulatory strength, and adaptor (innovator) cognitive styles.

Proposition 2c: Variance. We propose that the degree of variation across individuals (e.g., personal dispositions, attitudes, expectations) is in part a function of the tightness-looseness of the societal context. In societies where there are strong norms that clearly prescribe appropriate behavior, individuals will share many common experiences, and thus will be likely to develop higher between-person similarities. By contrast, when norms are comparatively weaker and there is less constraint, people have more varied and idiosyncratic experiences, and thus, individual attributes will be more likely to diverge (cf. House, Rousseau \& Thomas-Hunt, 1995; Strauss \& Quinn, 1997). The degree of variation in individual differences across societies helps to reinforce and maintain the tightness-looseness of the societal context. Less variation in tight as compared to loose societies enables individuals to mutually reinforce normative expectations which ultimately enhances predictability and order.

Proposition 2c: Societal tightness-looseness affects variance across individuals in individual attributes (e.g., attitudes, beliefs). There will generally be less variance across individuals in tight versus loose societies.

Research Implications of Proposition $\mathbf{2 b}$ and 2c. Propositions $2 \mathrm{~b}$ and $2 \mathrm{c}$ have a number of important research implications. Many of the constructs discussed in Proposition $2 b$ (i.e., 
normative associative strength, ought self-guides, self-regulation strength) have received little attention in cross-cultural research. We advance that societal tightness-looseness has crosslevel effects on these constructs, thus potentially explaining new variance at the individual level. Moreover, these individual-level constructs largely exist in isolated literatures with different theoretical traditions, and there has been little theory advanced which highlights their underlying commonalities. By examining these individual level constructs within the context of external constraints in societies, we illustrate why these variables may be correlated at the individual level, as they all are indicative of a focus (or lack thereof) on adapting to existing normative requirements in the societal context. There are well-developed measures of many of these constructs that can be adapted for cross-cultural research (see Higgins, Friedman, \& Harlow, 2001, Seeley and Gardner 2003, and Kirton, 1976, for measures of prevention and promotion focus, regulatory strength, and cognitive styles, respectively). Cross-cultural differences in accessibility of normative requirements can be measured through nonobtrusive measures including reaction times (Aarts \& Dijksterhuis, 2003).

Proposition $2 \mathrm{~b}$ also illustrates how the external normative context influences psychological processes at the individual level, thus furthering our understanding of how external structuralist perspectives affect internal subjectivist phenomena. Individuals are socialized into the external normative context through key societal institutions, thereby developing psychological characteristics that fit with the cultural context. Once socialized, individuals sustain the predominant levels of tightness-looseness by further developing institutions that are consistent with their psychological characteristics. We return to these mutually reinforcing processes in Proposition 5a-b, and discuss the mediating mechanism of felt accountability characteristics on behavior in Propositions 3a-3b below. More generally, Proposition $2 b$ clearly differentiates the societal level from the individual level, and helps to avoid "levels of analysis" confusion that is endemic in the cross-cultural literature. Rather than discussing "tight" versus "loose" individuals, 
we advance a psychology of felt accountability and its constituent elements at the individual level that is qualitatively different from, but theoretically related to, societal-level constructs.

Lastly, Proposition 2c points to an important area for cross-cultural research, namely understanding and explaining variance within societies. With few exceptions (Au, 1999; Schwartz \& Sagie, 2000), research has focused exclusively on differences in means across cultures, and has rarely examined whether cultures vary predictably in terms of variance. Echoing these sentiments, Earley and Mosakowski (2002) recently asked, "Might other characteristics of a distribution (e.g., variance, skewness) convey important meaning concerning culture?" (p. 313). Proposition 2c begins to address the dearth of theorizing on this issue, illustrating that the degree of "sharedness" among individuals is likely to be a function of the strength of the external constraints that are encountered in the societal context. This proposition also has a number of methodological implications. It suggests that cross-cultural research should begin examining dispersion constructs (e.g., $r_{\text {wg }}$; standard deviation; coefficient of variation; Chan, 1998) as important dependent variables in and of their own right. Such data are as readily available as means in survey measures of attitudes and beliefs. Proposition $2 c$ could be tested by examining how measures of societal tightness-looseness relate to variability in societal beliefs (e.g., Leung, Bond, de Carrasquel, Munoz, Hernandez, et al., 2002), attitudes (Inglehart, Basañez, \& Moreno, 1998), and normative expectations. Other measures of shared mental models, such as pathfinder (Schvaneveldt, 1990) and cognitive mapping (Bougon, 1983) can assess variance across cultures. From a methodological perspective, Proposition 2c suggests that research should move beyond using measures of dispersion within cultures only to justify aggregation, as such variance measures may be indicative of important cultural differences.

\section{Societal Tightness-Looseness and Cross-Level Effects on Individual Behavior}

In Propositions $3 \mathrm{a}$ and 3b, we discuss the effect that societal tightness-looseness has on individual-level behavior and variability in behavior as mediated by the psychological attributes 
previously discussed. First, individuals in tight and loose societies differ in their willingness to conform versus act in socially deviant ways. This is consistent with work by Tetlock and others that has shown that felt accountability induces conformity when normative standards are known (Cummings \& Anton, 1990; Lerner \& Tetlock, 1999; Tetlock, 1992; Tetlock, Skitka, \& Boettger, 1989), as well as with research that has shown that individuals who prefer predictability and order rely on well-learned scripts to guide their behavior (Chiu. Morris, Hong, \& Menon, 2000).

Second, individuals in tight and loose societies differ in their willingness to engage in risktaking and innovative behaviors as compared to risk-avoidance behaviors. Individuals who have a high promotion focus (Crowe \& Higgins, 1997; Friedman \& Forster, 2001; Levine, Higgins \& Choi, 2000), positive attitudes toward errors (Rybowiak, Garst, Frese, \& Batinic, 1999), and an openness to experience (George \& Zhou, 2001)—all attributes we expect to be cultivated in loose societies_-tend to engage in more risk-taking and innovative behavior. Individuals who seek predictability and order, by contrast, tend to avoid ambiguous and novel situations (e.g., Moskowitz, 1993; Neuberg \& Newsom, 1993), and are generally less creative (George \& Zhou, 2001). As George \& Zhou (2001) explain, “conforming, controlling one's impulses, following rules, and striving to achieve predetermined goals all may go against seeking to change the status quo and coming up with new and better ways of doing things" (p. 515).

Third, individuals in tight and loose societies differ behaviorally in their openness to change versus preference for stability. This is consistent with research that has shown that a prevention (versus promotion) focus is negatively associated with changing one's course of action (Liberman, Idson, Camacho, \& Higgins, 1999), and with research that has shown that a fear of errors and mistakes, a mindset we expect is common in tight cultures, is also related to resistance to change (Rybowiak et al. 1999; see also Judge, Thoresen, Pucik, \& Welbourne, 1999).

Proposition 3a: Societal tightness-looseness has cross-level effects on individual behavior as mediated by felt accountability psychological attributes. Individuals in tight societies will tend to enact behaviors characteristic of conformity, risk-avoidance, and 
stability seeking, whereas individuals in loose societies will tend to enact behaviors characteristic of deviance, risk-seeking, and openness to change.

The above discussion also implies that there will be less variability in individual behavior in tight than loose societies. In societies where there is more conformity, less risk-taking, and an emphasis on stability, there will be greater similarity across individuals in their behaviors across situations. By contrast, in societies where there is more deviance, more risk-taking, and openness to change, there will be greater idiosyncrasy in behaviors of individuals across situations.

Proposition 3b: Societal tightness-looseness affects variability in behavior. Behavior across individuals is more variable in loose than in tight societies.

Research Implications of Proposition $\mathbf{3 a}$ and $\mathbf{3 b}$. Propositions $3 \mathrm{a}$ and $3 \mathrm{~b}$ suggest a number of directions for future research. Proposition 3a illustrates the "value" of moving beyond values in cross-cultural research. Cross-cultural differences in behavior need not always be linked to values or "guiding principles one has in life"-but may also be explained by felt accountability that is derived from external constraints and normative requirements in the societal context. Conceptually, this is consistent with Fishbein \& Ajzen (1975) who showed that behavior is a function of attitudes as well as perceptions of subjective norms. Moreover, this approach may explain why values do not always consistently predict behavior in cross-cultural research (Bond, 1997). For example, Proposition 3a would suggest that perceptions of the normative context are likely to loom large in predicting behavior in tight societies, whereas one's individual values may predict behavior more in loose societies.

Proposition $3 \mathrm{a}$ also highlights the need to study behaviors such as deviance and openness to change across cultures. Data on these issues can be examined by adapting existing measures of deviance, innovation, and coping with change for cross-cultural research (see Bennett \& Robinson, 2001, George \& Zhou, 2001; Judge et al., 1999, respectively). Likewise, laboratory studies can be designed to examine cross-cultural differences in risk-taking and willingness to change courses of action. For example, data could be collected across cultures 
using Liberman et al.'s (1999) paradigm to see if individuals in loose societies are more likely to change their course of action when given the opportunity in an experimental task as compared to individuals in tight societies (see also Levine et al., 2000). Finally, Proposition 3b highlights the need to study cultural variation in variability of behavior. Measures of variability of behavior are as readily available as measures of means and should also be reported in cross-cultural studies.

\section{Organizational Adaptations to Tightness-Looseness: Top-Down and Bottom-up}

\section{Processes}

We next consider cross-level effects of societal tightness-looseness on organizational phenomena. Figure 1 illustrates that organizational culture and practices, as well as organizational culture strength, are related to societal tightness-looseness through both topdown and bottom-up processes.

Top Down Effects of Societal Tightness-Looseness on Organizations. Organizational theorists have long argued that work institutions are open systems that perpetuate and reinforce dominant norms in the societal context (e.g., Emery \& Trist, 1965; Katz \& Kahn, 1978). We argue that there are top-down, cross-level societal effects such that work organizations generally reflect the degree of tightness-looseness in the larger society. Organizations in tight societies generally have cultures of high constraint, wherein there are practices that limit the range of acceptable behavior and facilitate order and predictability. Organizations in loose societies generally have cultures with more latitude, wherein there are practices that allow for a wider range of acceptable behavior, and which facilitate experimentation, openness, and risktaking.

The notion that organizational cultures differ on the extent to which they emphasize rules and predictability versus flexibility and experimentation has a long history in the organizational sciences (Litwin \& Stringer, 1968; O'Reilly, Chatman, \& Caldwell, 1991; O'Reilly \& Chatman, 1996; Quinn, 1988; Rousseau, 1990). Quinn (1988) described flexibility versus control as one of 
the most important dimensions that differentiate organizational cultures. In their Organizational Culture Profile (OCP), O'Reilly et al. (1991) contrasted organizations that emphasize innovation (e.g., experimentation, risk-taking, not being rule oriented) with those that emphasize stability (e.g., rule-oriented, focused on predictability, stability). Research outside of the U.S. has also shown that flexibility and experimentation versus rule orientation is a central dimension of organizational culture (Dastmalchian, Lee, \& Ng, 2000; Hofstede, Neuijen, Ohayv, \& Sanders, 1990; Verberg, Drenth, Koopman, van Muijen, and Wang, 1999).

Although there has been little theorizing on societal top-down effects on organizational rules versus flexibility, there is some indirect evidence that supports our linkage of societal tightnesslooseness to this dimension of organizational culture. Dastmalchian et al. (2000) found that Korean organizations were higher on rigidity and control than Canadian organizations. Likewise, Morishima (1995) characterized many organizations in Japan as learning bureaucracies wherein "codified rules and legitimized practices all work to rationalize Japanese employment and bring predictability and control to the behavior of the major actors, employees and employers" (p. 119). Wächter \& Stengelhofen (1995) argued that organizations in Germany generally have many rules and monitor individuals through extensive and detailed record keeping.

Proposition 4a: Societal tightness-looseness has cross-level effects on organizational culture. Organizations in tight societies generally emphasize rules and predictability and have cultures of higher constraint. Organizations in loose societies generally emphasize flexibility and experimentation and have cultures of lower constraint.

Societal tightness-looseness also has top-down effects on a number of organizational practices. We expect that selection and recruitment strategies will be much stronger in organizations in tight versus loose societies, meaning that organizations in tight societies will seek to restrict the range of individuals who enter the organization, and to select individuals who match the organizational culture to a greater extent than organizations in loose societies. For example, Japanese organizations have historically given preference to recruiting from a narrow range of universities (Fliaster, 2001), and to recruiting individuals within cohorts at the same 
time every year so they have similar experiences (Morishima, 1995). Similarly, upper level managers in many British organizations have historically been educated at Eton and then at Cambridge or Oxford (Hambrick \& Mason, 1984). Relying on a more narrow range of sources that are very well known to employers can increase the reliability of information about potential employees, and hence increase predictability about how they will fit into the organization.

Likewise, the types of attributes that are emphasized during the selection process are expected to vary in tight and loose societies. Identifying knowledge, skills, and abilities of employees in order to match the requirements of the job is expected to be the primary emphasis of selection in loose societies. The match of the person to the organizations' norms-selecting those who will fit into and support the existing culture-is expected to be the primary emphasis in tight societies. For example, Fujiwara (1993) found that fewer than $10 \%$ of organizations in Japan indicated that they prioritized technical expertise in the selection process; rather, important criteria for selection included the trainability of potential candidates and their ability to be good organizational citizens and uphold organizational standards (Morishima, 1995).

Further, socialization and training processes will be more pervasive in organizations in tight versus loose societies, as intensive training and socialization is essential for conveying organizational standards and enhancing accountability (Aoki, 1988; Morishima, 1995; Redding, Norman, \& Schlander, 1994). For example, as compared to their American counterparts, employees in Japanese companies participate in longer and more extensive formal orientation programs and continue in training and socialization efforts for much longer (Lincoln \& Kalleberg, 1985; Moroshima, 1995).

Finally, there will be more well-developed performance monitoring systems in organizations in tight as compared to loose societies. In tight societies, employees are monitored more on a continual basis and are punished more severely for violating organizational norms. In many Japanese organizations, for example, there is continuous assessment of employee behavior (Aoki, 1988; Jennings, Cyr \& Moore, 1995; Morishima, 1995), and employees expect to receive 
strong sanctions for occupationally deviant behavior, and perceive much greater threats of shame for such acts, as compared to Americans (Kobayashi, 1998). Similarly, in Saudi Arabia and Iran, workplace behavior that deviates from Islamic teachings is seen as a threat to organizational stability and is generally not tolerated (Ali, 1993; Mellahi \& Wood, 2001; Tayeb, 2001).

Proposition 4b: Societal tightness-looseness has cross-level effects on organizational practices pertaining to control versus flexibility. Organizations in tight societies generally have stronger recruitment, selection, and training practices, and have more welldeveloped performance monitoring systems, as compared to organizations in loose societies.

Research Implications of Propositions 4a and 4b. Propositions $4 \mathrm{a}$ and $4 \mathrm{~b}$ highlight a number of future directions for cross-cultural research. Theory and research linking societal and organizational culture is relatively rare, despite the recognition that organizations are open systems that are influenced by the societal context. A critical challenge is to develop theory that links specific societal dimensions of culture with specific organizational dimensions of culture (e.g., Aycan, Kanungo, \& Sinha, 1999; House et al., 2004). The dimension of organizational flexibility versus control has consistently been demonstrated to be a key aspect of organizational culture, yet little research has examined the dimensions of societal culture that influence this aspect of organizational culture. Accordingly, Proposition $4 a$ offers a novel theoretical linkage that should be examined in future research. Multilevel modeling techniques that link measures of societal tightness-looseness with measures of organizational flexibility versus control (e.g., Dastmalchian et al., 2000; O'Reilly et al., 1991) can be used to test this proposition. Ethnographic techniques (Wilkins \& Ouchi, 1983) can also be used to assess crosscultural variation in organizational flexibility vs. control.

Proposition 4a also has some important implications for global organizations that need to "negotiate" between the organizational cultures of their home and host organization. To the extent that there is societal variation in organizational flexibility and control, this could create cultural conflicts among joint ventures and acquisitions that take place between organizations 
from tight and loose societies. Future research would benefit from examining conflict and performance among joint ventures between organizations from tight and loose societies. The performance of international joint ventures (IJVs) can be assessed through objective performance measures including profitability and growth, and survival, stability, and duration of the IJV, as well as through subjective measures such as IJV partners' satisfaction (Geringer \& Herbert, 1991). Relatedly, it would also be useful to examine the process of integration in joint ventures between organizations from tight and loose societies. For example, organizations from tight societies would likely exercise greater control in international joint ventures (cf. Pan 2002) and maintain greater uniformity in practices across its global units (i.e., globalize rather than localize its practices). Research can examine whether there are cultural differences in globalization versus localization of practices with measures that assess whether the focal firm's human resource management practices are similar to those of the MNC's home country operations (for examples, see Lu \& Bjorkman, 1997; Rosenzweig \& Nohria, 1994).

Finally, Proposition 4b advances the international human resource management (IHRM) literature by linking societal tightness-looseness with specific organizational practices that receive little cross-cultural research attention. This proposition can be tested by examining cross-level effects of societal tightness-looseness on the adoption of organizational practices that constrain versus permit variability in employee behaviors. Such data are readily available, for example, from the Cranfield Network on Comparative Human Resource Management (CRANET), which collects longitudinal, standardized data on recruitment and selection activities, flexibility and alternative working practices, employee development, and employee compensation and benefits in over 30 countries (e.g., Brewster, Communal, Farndale, Hegewisch, Johnson, \& van Ommeren, 2000). This proposition also has implications for attraction-selection-attrition (ASA) processes (Schneider, 1987) across societies. To the extent that organizations in tight societies have much more restrictive recruitment and selection processes, and further, individuals who do not fit the context are much more likely to be 
mistreated in tight societies (see Proposition 10), we would expect that the ASA model, and its consequences for increased homogeneity in organizations, would be even pronounced in tight societies. Research on the ASA model in non-Western cultures is rare, and thus, cross-cultural research on this model is an important research direction (see Schneider, Smith, Taylor, \& Fleenor, 1998; Ziegert, 2002 for tests of the ASA model).

Societal Tightness-Looseness and Variance in Organizations. Societal tightnesslooseness also has implications for variance in organizations. The organizational practices discussed above collectively produce homogeneity (i.e., consensus) in perceptions about organizational norms and practices, and thus produce "strong" organizational cultures. Organizations with strong cultures have clear and agreed-upon norms that guide employees' perceptions of appropriate actions (Cooke \& Rousseau, 1988; Cooke \& Szumal, 1993; O'Reilly \& Chatman, 1996). To the extent that there is intensive socialization and training, continuous feedback and performance appraisal, and recruitment and selection systems that ensure that experiences are shared among employees, there will be stronger organizational cultures in tight societies and comparatively weaker organizational cultures in loose societies. This is consistent with research that has shown that the extensiveness of socialization practices is associated with employees' shared perceptions of the work environment (Malamaut, 2002; Peterson, 1984), as well as with research that has shown that accountability in organizations produces higher socially shared cognition (Frink \& Klimoski, 1998; Rozelle \& Baxter, 1981),

Homogeneity of thought is also facilitated in organizations in tight societies by a high degree of alignment or "bundling" across organizational practices that communicate similar expectations to individuals (Baird \& Meshoulam, 1988; Bowen \& Ostroff, 2004; Delery, 1998; Wright \& McMahan, 1992). Morishima (1995) describes how human resource management systems in Japan are aligned to enhance the acquisition of knowledge and to create socially shared understandings of that knowledge. In loose societies, alignment across organizational practices is expected to be lower, and there is more inconsistency in the messages sent through 
organizational practices. Similar to parents having more latitude to socialize their children, managers in loose societies are likely to be given discretion in deciding how (or whether) to implement organizational practices and procedures, which further enhances the likelihood that employees receive divergent messages about the organizational context. Consistent with this notion, Crossland \& Hambrick (2005) found that managerial discretion is greater in the U.S. as compared to Japan and Germany. In all, both the nature of organizational practices (e.g., intensive socialization, continuous feedback), and the alignment across organizational practices, results stronger (versus weaker) organizational cultures in tight (versus loose) societies.

Proposition 4c: Societal tightness-looseness has cross-level effects on the strength of organizational cultures. There are stronger organizational cultures and higher alignment across practices in organizations in tight as compared to loose societies.

Research Implications of Proposition 4c. Proposition 4c points to the importance of examining organizational culture strength as it relates to societal culture. The issue of organizational culture strength has received increasing attention in the literature, yet the role that the societal context plays in organizational culture strength has received scant attention. This proposition can be tested by examining the relationship of societal culture measures with measures of climate and culture strength (e.g., standard deviation, variance, or average deviation indices; Gonzales-Roma, Peiro, \& Tordera, 2002; Lindell \& Brandt, 2000; Schneider, Salvaggio, \& Subriats, 2002). Likewise, the study of alignment of organizational practices has received increasing attention, yet has not been examined from a cross-cultural perspective. Research can examine the cross-level relationship between societal tightness-looseness and measures of alignment in organizations, either through surveying managers about the extent to which they perceive their organizational practices as being consistent (e.g., Becker, Huselid, \& Ulrich, 2001), or by surveying employees about the extent to which they perceive consistent messages across HR practices (Ostroff \& Bowen, 2000; Nishii \& Wright, in press).

Bottom-Up Processes Reinforcing Tightness in Organizations. Bottom-up processes that relate psychological characteristics to organizational characteristics are also an important 
component of our model. To the extent that individuals in tight societies have higher felt accountability (e.g., high accessibility of normative requirements, a prevention regulatory focus, high regulatory strength), they will establish shared norms that emphasize order, predictability, and control. By contrast, to the extent that individuals in loose societies have lower felt accountability (e.g., low accessibility of normative requirements, a promotion regulatory focus, low self-regulatory strength), they create and sustain norms that emphasize flexibility, experimentation, and risk-taking. Put differently, through social interactions, employees' psychological attributes and behaviors become amplified and manifested in higher-level collective phenomena (Kozlowski \& Klein, 2000). For example, Levine et al. (2000) subtly manipulated groups' promotion versus prevention focus on a memory recognition task, and demonstrated that over time, groups with a prevention focus converged on risk-averse solutions, whereas groups with a promotion focus converged upon risky solutions. Accordingly, the development of shared collective realities in organizations based upon individuals' characteristics is one important bottom-up mechanism through which levels of tightnesslooseness in organizations are developed and sustained.

Proposition 5a: Through bottom-up processes, psychological felt accountability characteristics (e.g., accessibility of normative requirements, regulatory focus and strength) influence the level of tightness and looseness in organizations.

Bottom-up processes in tight and loose societies also further contribute to the strength of organizational cultures discussed above. Higher socially shared cognition and lower variability in behavior make it easier for the bottom-up emergence of strong organizational cultures to occur in tight societies. Likewise, bottom-up emergence is more likely to occur in contexts where there is a high degree of social influence pressures, intensive social interaction, and strong socialization (Kozlowski \& Klein, 2000), all of which are more common in tight societies. And as we will discuss more at length below, because the consequences of (mis)fit are much more acute in tight societies, individuals who are different are more likely to leave organizations, 
further enhancing the emergence of strong organizational cultures in tight versus loose societies.

Proposition 5b: Through bottom-up processes, psychological felt accountability characteristics (e.g., accessibility of normative requirements, regulatory focus and strength) influence the strength of organizational cultures.

Research Implications of Proposition 5a and 5b. To date, much of the literature has focused on top-down effects of societal culture. Propositions $5 \mathrm{a}$ and $5 \mathrm{~b}$ recognize that bottomup processes—which link individuals' attributes to organizational phenomena —are yet another mechanism through which cross-cultural differences are reinforced and sustained. Several possibilities emerge for future research. Qualitative and quantitative research methods could examine the types of group norms that emerge over time across cultures as a function of the "felt accountability" attributes discussed previously. For example, following the methodology of Bartel and Saavedra (2000) who examined the collective construction of group moods, one could use observational techniques to code the verbal and nonverbal elements of group interactions that encourage flexibility versus control across cultures. Quantitative methodologies for longitudinal data analysis (e.g., latent growth modeling; Chan, 2003) will also be useful for examining the emergence of group norms regarding flexibility and control across time as a function of a cultural group's profile on felt accountability characteristics.

\section{Organizational Context Factors and Societal Tightness-Looseness}

Before turning to the outcomes associated with tightness-looseness within organizations, we briefly discuss organizational context factors that also affect tightness and looseness in organizations. It would be an oversimplification to argue that there are only societal forces that affect tightness-looseness in organizations. Proposition 6 a illustrates that there are a number of organizational context variables that affect the degree to which organizations are tight versus loose within all societies. For example, in all societies, high risk organizational systems are expected to be tighter as compared to low risk organizational systems. In nuclear power plants, a prototypical high risk system, there are many rules and mutual monitoring in order to minimize 
the potential for catastrophic error (Klein, Bigley, \& Roberts, 1995). As a general rule, organizations in all societies that deal with conditions of great threat, danger, and vulnerability (e.g., the Army) are expected to be tighter, regardless of the societal culture context. As McKelvey (1982) cogently argued, "Environmental threat more than anything else seems to be accompanied by organizations having tight and extensive control systems" (p. 186).

Organizational life stage is also expected to affect the degree to which organizations emphasize tightness or looseness, with young start-up firms being looser (e.g., emphasizing flexibility, experimentation) and older, more mature organizations being tighter (e.g., emphasizing rules, stability, predictability) (cf. Hanks, Watson, Jansen \& Chandler, 1993; Olson \& Terpstra, 1992). Ownership is also predicted to relate to tightness-looseness in organizations. Public organizations tend to have many rules, strict reporting requirements, and clear control mechanisms because of their multiple stakeholders and lack of market incentives (Marsden, Cook, \& Knoke, 1994). By comparison, private organizations tend to be more flexible and innovative because they are not as restricted by external rules and governing bodies, and market pressures dictate flexibility for survival (Kurland \& Egan, 1999).

Finally, in our model, societal tightness-looseness directly affects the contexts in which organizations are embedded (Proposition 6b). For example, we expect that there will be more public organizations as well as mature and firmly regimented organizations that persist in tight as compared to loose societies. Put differently, organizational forms and industries that are consonant with the broader societal emphasis on flexibility and control are most likely to prosper and thrive in a given society. This notion can be traced to Adam Smith (1776) and David Ricardo (1817), who argued that countries excel by specializing in the organizational forms in which they posses comparative advantage.

Proposition 6a: Tight versus loose organizational cultures are influenced by features of the organizational context (e.g., risk, age, and ownership).

Proposition 6b: Societal tightness-looseness influences features of organizational context. 
Research Implications of Propositions $6 \mathbf{a}$ and $\mathbf{6 b}$. Propositions $6 \mathrm{a}$ and $6 \mathrm{~b}$ point to some needed directions for cross-cultural research. Cross-cultural research and theory often treats organizational phenomena as being unitary within national cultures (Aycan, et al., 1999), when in fact, there is much organizational variation within societies due to powerful institutional forces (e.g., industry, ownership) and organizational variables (e.g., size, structure, technology) (Chatman \& Jehn, 1994; Gordon, 1991). A key theoretical challenge is to identify specific organizational context factors that are associated with specific dimensions of organizational culture. Proposition $6 a$ begins to fill this void by pointing to particular contextual forces that can produce variation in tightness and looseness in organizations within societies, opening up relatively uncharted territory for organizational research (see also Dastmalchian et al., 2000). Proposition 6a also links previously isolated contextual phenomena through a common lens. For example, our review illustrates some theoretical similarities among organizational context factors such as industry, environmental vulnerability, and life stage that may not have been readily apparent previously. This proposition can be tested by linking archival data that assesses organizations' industry, core processes, size, age, and ownership characteristics with measures of organizational flexibility versus control. Finally, Proposition $6 \mathrm{~b}$ recognizes that there could be societal variation in organizational context variables, thereby suggesting a new way to think about cross-cultural research that should be of interest to macro organizational scholars.

\section{Tightness-Looseness and Organizational Outcomes}

Tightness-looseness brings both benefits and detriments to organizations, which are quasiisomorphic with the individual-level outcomes discussed previously. Based on the previous discussion of organizational culture, culture strength, and alignment among HR practices, it follows that organizations in tight societal cultures will generally have greater order, precision, cohesion, and efficiency, and will be more stable, less flexible, and more resistant to change (cf. Ostroff \& Bowen, 2000; Schneider et al., 2002; Sorenson, 2002). Also, due to high 
accountability, alignment, and sanctioning, employees are more likely to conform and less likely to engage in deviant behavior. Furthermore, although extensive recruitment, selection, and socialization processes increase organizational predictability and control, these practices may hinder organizations in tight cultures in their ability to quickly adapt to changing conditions. ${ }^{3}$

By contrast, organizations in loose societies generally have less order and cohesion, yet greater innovation and more tolerance for organizational change. In organizations where there is less accountability and sanctioning, employees have much more discretion and a wider range of acceptable behavior. This enables higher levels of organizational creativity and innovation, as a diversity of expressed ideas and behaviors is generally associated with greater innovativeness (Cox, Lobel, \& McLeod, 1991). Less rigidly shared perceptions and loosely coupled organizational practices in loose societies also foster a wider repertoire of behavioral scripts among employees, further facilitating flexibility and openness to change (Schneider, Goldstein, \& Smith, 1995; Wright \& Snell, 1998). However, although creativity and change are fostered in organizations in loose societies, these same processes may result in less predictability and order and a greater degree of deviant behavior.

Proposition 7: Societal tightness-looseness has cross-level effects on organizational outcomes as mediated by organizational culture and culture strength. Organizations in tight societies will tend to have greater order, precision, cohesion, stability, and resistance to change. Organizations in loose societies will tend to have less order and cohesion, and more deviance, innovation, and tolerance for organizational change.

Research Implications of Proposition 7. Proposition 7 highlights the importance of understanding how organizational level outcomes are indirectly affected by the societal context. Scholars are increasingly interested in the individual and organizational-level factors that predict organizational innovation and change. Yet with few exceptions (e.g., Elenkov \& Manev, 2005; Herbig \& Dunphy, 1998; Jones \& Davis, 2000; Shane, 1992), research on societal predictors of these outcomes is still in its infancy. Indeed, Anderson, De Drue, and Nijstad (2004) recently argued that there is a "pointed gap in our understanding of innovation processes across different cultural contexts, and one that we raise as an important pathway for future research" 
(p. 160). Proposition 7 has the potential to explain additional variance in these organizational outcomes by advancing that societal level tightness-looseness, through its cross-level influences on organizational culture and culture strength, influences organizational innovation and change. This proposition can be tested with multilevel modeling techniques that link measures of societal tightness-looseness with measures of organizational innovation rates, such as the number of new products, patents, and services (see Bantel \& Jackson, 1989; Burpitt \& Bigoness, 1997). To examine the notion that tight societies have higher precision and control, quality measures such as the number of defect-free products and amount of time wasted on repairing rejected products (Naveh \& Erez, 2004) could be examined across cultures.

Research can also examine whether organizations in loose societies have more "radical" innovations whereas organizations in loose societies have more "incremental" innovations. Organizations in tight and loose societies might vary in how they allocate R\&D funds (e.g., to doing basic research which is aimed at new, radical innovations, versus to improving existing process or product technology). At the same time, although innovations may be developed with greater speed and frequency in loose societies, implementation rates (e.g., time to market measures) might be faster in tight societies (Katz, Casey \& Aiman-Smith, 2005; Wong, 2002). More generally, this proposition illustrates the value of examining how organizational outcomes are influenced by societal-level culture as mediated by differences in organizational culture.

\section{Tightness-Looseness and the Importance of Fit Across Levels of Analysis}

In this final section, we discuss the dynamics of fit and misfit in tight and loose societies at multiple levels of analysis. Our primary proposition is that because there is more constraint and monitoring in tight societies, parties (i.e., individuals, groups, organizations) are much more concerned about "fitting in" with others, and thus, misfit between parties will have more negative consequences in tight than in loose societies. We discuss cross-cultural differences in fit at three levels of analysis: 1) fit of organizational practices to the societal context, 2) fit of organizations to other organizations, and 3) fit of individuals to organizations. 
Fit of Organizational Practices to the Societal Context. Societal tightness-looseness is proposed to moderate the impact of organizational practices on organizational outcomes. Organizational practices that are congruent with the degree of tightness-looseness in the societal context are more likely to be successful in organizations than organizational practices that are not congruent with the societal context. For example, practices that entail a high degree of accountability, monitoring, and control (such as those found in high-reliability, quality-focused manufacturing processes, including total quality management (TQM) and the International Organization for Standardization's ISO 9000 program), will be more successful in tight as compared to loose societies. This is consistent with research that shows that American companies have high failure rates (approximately 70\%) when implementing the regimented monitoring systems associated with ISO 9000 (Souza-Poza, Nystrom, \& Wiebe, 2000; Withers \& Ebrahimpour, 1996). By contrast, consistent with our proposition, Japanese and Singaporean organizations have a much higher level of success in implementing TQM programs (Dahlgaard, Kristensen, Kanji, Juhl, \& Sohal, 1998; Sohal, 1998).

Our former discussion helps to elucidate why such TQM practices are likely to be met with more success in tight than loose societies. A high degree of accountability and monitoring is more natural in tight societies, and individuals have psychological attributes (e.g., high normative associative strength, regulatory strength, prevention focus) that are attuned to and supportive of such practices. By contrast, a high degree of control and monitoring in loose societies likely elicits negative reactions among employees (Frink \& Klimoski, 1998). This is consistent with Lerner \& Tetlock's (1999) notion that a high degree of accountability and external controls are often met with resistance, and we argue that this is particularly acute in loose societies. Field studies in the U.S. of organizational accountability have indeed shown that monitoring often disrupts performance due to negative emotional reactions (Sutton \& Galunic, 1996), as workers complain about the loss of control in the way that they perform their jobs (Aiello \& Kolb, 1995), even to the point of seeing monitoring as a form of oppression (Martin \& 
Freeman, 2003). We expect that organizations in loose societies will have greater success with implementing organizational practices aimed at creativity and innovation due to their fit with the psychological characteristics that are cultivated (e.g., promotion focus, innovator styles), and their fit with the high degree of latitude in societal context. By contrast, encouraging organizational innovation may be met with resistance in tight societies, where compliance with established norms for work are commonplace, and psychological characteristics encourage individuals to maintain existing structures rather than to break with established traditions.

Proposition 8: The relationship between organizational practices and organizational outcomes will be moderated by the level of societal tightness-looseness. Practices that entail a high degree of accountability, monitoring, and control (e.g., TQM) will be more successful in organizations in tight societies, whereas practices that entail a high degree of creativity and innovation will be more successful in organizations in loose societies.

Institutional Pressures and Between-Organization Fit. We propose that societal tightness-looseness moderates the degree of similarity that exists across organizations. This notion is based within institutional theory (DiMaggio \& Powell, 1991), which suggests that organizations are pressured to conform to external standards to gain legitimacy and tend to become similar (i.e., isomorphic). Isomorphism may occur either because organizations feel coercive pressure from the society to conform to what other organizations are doing, mimetic pressure to imitate what other organizations are doing when faced with ambiguity, or normative pressure to select and promote professionals who are similar to each other (DiMaggio \& Powell, 1991). Regardless of the form of pressure, institutional theory posits that organizations increasingly come to reflect the same rules that have been institutionalized and legitimated in the nation state (Hamilton \& Biggart, 1988; Jepperson \& Meyer, 1991).

Extending this theory across cultures, we propose that there will be stronger isomorphic pressures (i.e., coercive, mimetic, normative) for organizations in tight societies given the importance of abiding by norms and avoiding being deviant. As such, we anticipate a narrower range of organizational forms in tight than loose societies. There is some indirect evidence for this proposition. Orru, Biggart and Hamilton (1991) discuss the elaborate systems of control that 
are in place in Japan and Korea which constrain organizational forms and enhance homogenization across organizations. In Japan, six coalitions of highly successful organizations (intermarket firms or kigyo shudan) are virtually indistinguishable in their organization. For example, they each have a similar line-up of competing companies across sectors, their own financial institutions, and a President's Club made up of leading companies' presidents who meet once a month. The leading enterprise groups in Korea, or chaebol, are also similar, with organizations predominantly controlled by a single family and organized through a central holding company. Systems of control are also enforced by state regulations. As Hamilton and Biggart (1988) explain, "a firm that does not respond as expected to particular incentives may find that its tax returns are subject to careful examination, or that its application for bank credit is studiously ignored" (p. s77). By contrast, there will be less homogeneity across organizations in loose societies where there are fewer societal controls and less concern with "fitting in."

Proposition 9: Societal tightness-looseness influences the degree of betweenorganization fit in organizational practices, such that organizations in tight societies are subjected to greater isomorphic pressures than are organizations in loose societies.

Tightness and the Negative Consequence of Misfit for Individuals. Lastly, at a micro level of analysis, we propose that the misfit between individuals and the groups/organizations to which they belong has more negative consequences in tight than in loose societies. Lincoln, Hanada, and Olson (1981) demonstrated that Japanese experienced more satisfaction and social integration when they fit the organizational context, yet Americans' satisfaction and social integration were less affected by their fit with the organizational context. Similarly, Wiersema and Bird (1993) found that top management team heterogeneity was even more strongly predictive of team turnover in Japan, as compared to previously conducted research in the U.S. They argued that these results reflect the heightened sensitivity to differences in Japan, which is consistent with our theory of tightness-looseness.

The negative consequences of misfit are particularly detrimental for individuals in tight societies due to the negative interpersonal dynamics that transpire when individuals deviate 
from others. Research on bullying in organizations has shown that people who are deemed deviant by their coworkers may become targets of frequent personal attacks or isolation (Leymann, 1996; Namie \& Namie, 2000). While bullying processes exist in numerous nations, they may be particularly acute in tight cultures. It has been recognized for some time that Japanese children who are different from others experience "ijime," or bullying aimed at enforcing conformity to social norms (Kidder, 1992; Rios-Ellis, Bellamy, \& Shoji, 2000; Takemura \& Takagi, 1988). In an LA Times report, Magnier (1999) noted that, "While bullying has long been evident in Japanese schools and companies as a form of social control, workplace experts say its use has never been so widespread or so pointedly focused on getting large numbers of people to quit." We suggest that although such processes occur in loose societies, they are more acute in tight societies where deviance is less tolerated.

Proposition 10: Misfit between individuals and groups/organizations will produce more negative consequences for individuals in tight as compared to loose societies.

Research Implications of Propositions 8-10. In his analysis of the organizational fit literature, Schneider (2001) remarked that"...national culture must enter the equation for person-environment fit research. It must but it has not" (p. 148). Propositions 8-10 heed this call, and suggest new research directions on how societal culture influences fit across levels of analysis. Proposition 8 suggests that the implementation of certain organizational practices (e.g., quality control versus innovation) will be differentially successful depending on the societal context. Although it is known that failure rates for quality-control procedures (e.g., ISO9000) vary across societies (Souza-Poza et al., 2000; Withers \& Ebrahimpour, 1996), there has yet to be a coherent explanation for this finding. Our linkage of this phenomenon to societal tightnesslooseness can be examined through field experiments that directly assess the effectiveness of newly implemented quality control procedures (e.g., Naveh \& Erez, 2004) in tight and loose societies. Likewise, laboratory experiments could also be designed to examine how quality versus innovation-focused practices are linked to team performance in tight and loose societies. 
Proposition 9 points to the importance of societal tightness-looseness to another form of fit: between-organization fit. Although there is much research on institutional pressures, there has been little attention to how societal culture affects institutional pressures. Proposition 9 can be examined through multilevel modeling techniques that links societal tightness-looseness with between-organizational variability in organizational flexibility versus control.

Finally, Proposition 10 points to the importance of examining the relationship between societal culture and fit at the individual level. The notion that individuals in tight societies are acutely affected by a lack of fit can be tested with multilevel modeling techniques wherein societal tightness-looseness moderates the relationship between person-organization fit and/or person-team fit and satisfaction, stress, and turnover intentions (e.g., O'Reilly et al., 1991). Alternatively, policy-capturing designs (e.g., Kristof-Brown, Jansen, \& Colbert, 2002), or perceptual measures of fit (Ostroff, Shin, \& Kinicki, 2005), can be used across cultures to assess the notion that person-organization fit is a stronger determinant of individuals' outcomes in tight societies. Proposition 10 also suggests that the impact of diversity in teams would benefit from a tight-loose perspective. We know that diversity can have a negative impact on group processes and performance (Milliken \& Martins, 2001), and this may be exacerbated in tight cultures, where individuals may leave teams to which they are dissimilar at much higher rates. Likewise, this proposition may ultimately prove useful in understanding variation in expatriate return rates. We would speculate that expatriates going from loose to tight cultures would experience more difficulty in becoming integrated with host nationals, as compared to expatriates going from tight to loose cultures. Research can examine whether interaction, work, and general adjustment, and ultimately premature return rates (Black, 1999; Black \& Stephens, 1989), are lower when expatriates go from tight to loose societies versus from loose to tight societies. 


\section{Conclusion}

In this article, we advanced a multilevel theory and research agenda on tightnesslooseness, an important aspect of culture that has received scant theoretical and empirical attention. By applying this construct to modern societies, and organizations and individuals therein, we revitalize an important age-old construct and show its promise for cross-cultural research.

Our theory provides a roadmap for research on tightness-looseness that spans multiple levels of analysis. Following recommendations for multilevel theory building, we advanced topdown, bottom-up, and cross-level propositions linking societal tightness-looseness with individual and organizational-level phenomena. Through our propositions, we illustrated how societal tightness-looseness both affects, and, is in turn, further reinforced by lower level forces. For example, Propositions 2a-c illustrate that external norms and constraints affect internal psychological states (i.e., a psychology of felt accountability), which in turn, reinforce and sustain external norms and constraints. Propositions 4a-4c and Propositions 5a-b illustrate how organizational culture and culture strength are influenced by top-down effects of societal tightness-looseness, and are further reinforced through bottom-up processes based on psychological felt accountability. The theory also illustrates how societal tightness-looseness has a "ripple effect" on variance across multiple levels. Strong norms and sanctions in tight as compared to loose societies reduces variability across individuals' psychological attributes and behaviors, results in stronger alignment and strength of organizational cultures, and creates institutional forces that constrain variability across organizations. Our theoretical analysis also has important methodological implications. Scholars need to take note that a "lack of aggregation" using traditional techniques (e.g., Rwg, ICCs) in cross-cultural research could in fact have important substantive interpretations. Finally, many topics we discussed—from the psychology of accountability at the individual level, to organizational culture strength, alignment, and innovation at the organizational level, to the dynamics of fit within and across organizations 
in different societies-have received little cross-cultural attention, and thus, the theory has the potential to explain additional variance across societies that has been heretofore overlooked.

For reasons of space, we did not discuss ecological and historical correlates of societal tightness-looseness, yet this will be an important area for future research. Pelto (1968), Triandis (1989), and Chan et al., (1996) speculated that population density and isolation are correlates of societal tightness-looseness, and Gelfand (1999) proposed that history of conflict between nations may also result in stronger norms and sanctions in nations in order to deal with external threat. Likewise, we did not discuss societal-level outcomes, but there is reason to believe that tight and loose societies are differentiated in their degree of societal order and cohesion versus social disorganization, rates of innovation versus stability, and degree of conformity and deviance, in parallel to other levels of analysis. Indeed, sociological theorists have argued that weak normative systems result in numerous forms of delinquency, including bending the rules and various forms of retreatism (e.g., alcoholism) (Durkheim, 1893/1964; Merton, 1968). This is consistent with Baumeister and Heatherton's (1996) analysis of American culture, which they argued has numerous societal deviance problems (e.g., teenage pregnancy, drugs and alcohol abuse, assaults) that arise from a general "climate" of permissiveness and a lack of discipline and social control. We would extend this analysis by arguing that such societal phenomena are associated with societal tightness-looseness.

Practical implications. Although our primary purpose was to advance a theory of societal tightness-looseness, our analysis also has a number of practical implications. The model suggests a number of potential areas where cross-cultural conflicts can arise across the tightloose divide, with implications for international and global organizations and their employees. For example, Propositions 4a-4c suggest that organizations forming mergers across tight and loose societies might need to negotiate conflicts involving differences in organizational practices, culture strength, and alignment. Proposition 9 suggests that organizations that are expanding their operations across cultural boundaries may experience a heightened 
(dampened) number of institutional pressures if going to tight (versus loose) societies. Global organizations, as we have argued in Proposition 4b, are likely to have different preferences on standardization versus localization depending on the tightness-looseness of the societal context. At an individual level, Proposition 10 suggests that individuals are likely to experience much stress, especially when going from loose to tight societies. We also note, however, that individuals going from tight to loose societies will likely experience different sources of stress, most notably, a sense of normlessness, deviance, and ambiguity regarding behavioral expectations-which may conflict with their societally cultivated felt accountability. Proposition 2a illustrates the importance of understanding differences in societal institutions for individuals crossing tight and loose societies. The highly publicized incident of caning in Singapore (Shenon, 1994) is a case in point. Individuals traveling to tight and loose societies may face different sanctions for similar crimes and will encounter differences in the media, schools, etc. Finally, Propositions 2c, 3b, and 4c also illustrate that individuals crossing between tight and loose societal cultures will likely experience disparate levels of variance than they are accustomed to in their home countries. In all, our theory suggests that training should also focus on the strength of norms and sanctioning (or lack thereof) that individuals will face when crossing cultures, and not just on cultural values.

In this article, we discussed generalized societal tightness-looseness and advanced a multilevel model to help understand such variation. Yet we emphasize that there are likely domains, regions, or ethnic variation in tightness-looseness within societies as well. For example, although the U.S. is expected to be generally loose, there are also domains of life, ethnic groups, and regions that are relatively tighter. Thus, like other cultural dimensions, there are contexts in all societies that likely promote tightness and contexts that promote looseness. The basic psychological, social, and organizational processes discussed throughout this article, however, should be useful to understanding such variation. Likewise, our focus throughout this article has been on traditional work organizations, yet a tightness-looseness perspective is as 
applicable to "informal" organizations. For example, an understanding of tightness-looseness may help to understand such diverse groups as the Taliban, the military, and perhaps inner city gangs -in terms of the organizational practices and psychological attributes that make them up. Finally, although tightness-looseness was discussed as if it is a static phenomena, clearly as with other components of culture, it is can change over time, either through bottom-up or topdown changes, or through catastrophic changes that have a major impact on multiple levels.

\section{Concluding Remarks}

In a critique of the exclusive use of values as the basis for cultural comparisons, Bond (1997) cogently remarked:

"To date, the values construct has been our major support. Many of us have embraced it enthusiastically. Its face validity as a psychological construct, combined with Hofstede's mapping of cultural values gave us confidence in foreign territory. Our enthusiasm frequently outstripped our caution, however... many fundamental canons of cross-cultural procedure were ignored; many cautionary studies within mainstream psychology were ignored; alternative psychological constructs of possible use were ignored." (pp. 270-271)

Despite such calls to expand our "conceptual toolkit" (Bond, 1997), cross-cultural research has nevertheless been dominated by the values paradigm. Culture is a complex phenomenon, necessitating multilevel and multidisciplinary perspectives to adequately capture its breadth and depth, and an exclusive focus upon cultural values is insufficient to capture this complexity. The multilevel theory of cultural tightness-looseness presented in this article begins to tip the balance towards a more complete view of cultural differences. 


\section{References}

Aarts, H., \& Dijksterhuis, A. (2003). The silence of the library: Environment, situational norm, and social behavior. Journal of Personality and Social Psychology, 84, 18-28.

Aiello, J.R., \& Kolb, K.J. (1995). Electronic performance monitoring and social context: Impact on productivity and stress. Journal of Applied Psychology, 80, 339-353.

Ali, A. J. (1993). Decision-making style, individualism, and attitudes toward risk of Arab executives. International Studies of Management and Organization, 23, 53-73.

Amnesty International. (2002). Saudi Arabia. From http://web.amnesty.org/web/ar2002.nsf/mde/saudi+arabia?Open

Amnesty International. (2004). Singapore - The dealth penalty: A hidden toll of executions. From http://web.amnesty.org/library/Index/ENGASA360012004?open\&of=ENG-SGP

Anderson, N., De Drue, C. K.W., \& Nijstad, B. A. (2004). The routinization of innovation research: A constructively critical review of the state-of-the-science. Journal of Organizational Behavior, 25, 147-173.

Aoki, M. (1988). Information, incentives, and bargaining in the Japanese economy. New York: Cambridge University Press.

Arnett, J. J. (1995). Broad and narrow socialization: The family in the context of a cultural theory. Journal of Marriage and the Family, 57, 617-628.

$\mathrm{Au}, \mathrm{K}$. (1999). Intra-cultural variation: Evidence and implications for international business. Journal of International Business Studies, 30, 799-813.

Aycan, Z. (2000). Cross-cultural industrial and organizational psychology: Contributions, past developments, and future directions. Journal of Cross-Cultural Psychology, 31, 110-128.

Aycan, Z., Kanungo, R.N., \& Sinha, J.B. (1999). Organizational culture and human resource management practices: The model of culture fit. Journal of Cross-cultural Psychology, 30, 501-526.

Baird, L. \& Meshoulam, I. (1988). Managing two fits of strategic human resource management. Academy of Management Review, 13, 116-128.

Bandura, A. (1982). The self and mechanisms of agency. In J. Suls (Ed.) Psychological perspectives on the self (Vol. 1, pp. 3-39). Hillsdale, NJ: Erlbaum.

Bartel, C.A., \& Saavedra, R. (2000). The collective construction of work group moods. Administrative Science Quarterly, 45, 197-231.

Baumeister, R. F., \& Heatherton, T. F. (1996). Self-regulation failure: An overview. Psychological inquiry, 7, 1-15.

Becker, B.E., Huselid, M.A., \& Ulrich, D. (2001). The HR scorecard: Linking people, strategy, and performance. Boston, MA: Harvard Business School Press.

Bennett, R. J., \& Robinson, S. L. (2000). Development of a measure of workplace deviance. Journal of Applied Psychology, 85, 349-360.

Berry, J. W. (1966). Temne and Eskimo perceptual skills. International Journal of Psychology, 1, 207-229.

Berry, J. W. (1967). Independence and conformity in subsistence-level societies. Journal of Personality and Social Psychology, 7, 415-418.

Berry, J.W. (1975). An ecological approach to cross-cultural psychology. Nederlands Tijdschrift voor de Psychologie, 30, 51-84.

Black, J.S. (1988). Workrole transitions. A study of American expatriate managers in Japan. Journal of International Business Studies, 19, 277-294.

Black, J.S., \& Stephens, G.K. (1989). The influence of the spouse on American expatriate adjustment and intent to stay in pacific rim overseas assignments. Journal of Management, 15(4), 529-544.

Boldt, E.D. (1978a). Structural tightness and cross-cultural research. Journal of Cross-Cultural Psychology, 9, 151-165. 
Boldt, E.D. (1978b). Structural tightness, autonomy, and observability: An analysis of Hutterite conformity and orderliness. Canadian Journal of Sociology, 3, 349-363.

Boldt, E.D., \& Roberts, L.W. (1979). Structural tightness and social conformity: A methodological note with theoretical implications. Journal of Cross-Cultural Psychology, 10, 221-230.

Bond, M.H. (1997). Adding value to the cross-cultural study of organizational behavior: Reculer pour mieux sauter. In P.C. Earley \& M. Erez (Eds.), New perspectives in international industrial/organizational psychology (pp. 256-275). San Francisco: New Lexington Press.

Bond, M. H., Leung, K., Au, A., Tong, K-K., Chemonges-Nielson, Z. (2004). Combining social axioms with values in predicting social behaviours. European Journal of Personality, 18, 177-191.

Bougon, M.G. (1983). Uncovering cognitive maps: The self-q technique. In G. Morgan (Ed.), Beyond method: Strategies for social science research (pp.173-188). Beverly Hills, CA: Sage.

Bowen, D.E., \& Ostroff, C. (2004). Understanding HRM-firm performance linkages: The role of the "strength" of the HRM system. Academy of Management Review, 29(2), 203-221.

Brewster, C., Communal, C., Farndale, E., Hegewisch, A., Johnson, G. \& van Ommeren, J. (2000).Management research in practice series, Financial Times. New York: Prentice Hall.

Buckingham, M. \& Cuffman, C. (1999). First, Break all the Rules. New York: Simon \& Schuster.

Carpenter, S. (2000). Effects of cultural tightness and collectivism on self-concept and causal attributions. Cross-Cultural Research, 34, 38-56.

Carver, C. S., \& Scheier, M. F. (1981). Attention and self-regulation: A control theory approach to human behavior. New York: Springer-Verlag.

Chan, D. (1998). Functional relations among constructs in the same content domain at different levels of analysis: A typology of composition models. Journal of Applied Psychology, 83, 234-246.

Chan, D. (2003). Data analysis and modeling longitudinal processes. Group \& Organization Management, 28, 341-365.

Chan, D. K-S., Gelfand, M.J, Triandis, H.C., \& Tzeng, O. (1996). Tightness-looseness revisited: Some preliminary analyses in Japan and the United States. International Journal of Psychology, 31,1-12.

Chatman, J.A., \& Jehn, K.A. (1994). Assessing the relationship between industry characteristics and organizational culture: How different can you be? Academy of Management Journal, $37,522-553$.

Chen, X. (2000). Social and emotional development in Chinese children and adolescents: A contextual cross-cultural perspective. In F. Columbus (Ed.), Advances in psychology research, Vol. 1 (pp.229-251). Huntington, NY: Nova Science Publishers, Inc.

Chui, C.Y., Morris, M.W., Hong, Y.Y., \& Menon, T. (2000). Motivated cultural cognition: The impact of implicit cultural theories on dispositional attribution varies as a function of need for closure. Journal of Personality and Social Psychology, 78, 247-259.

Chiu, L.H. (1987). Child-rearing attitudes of Chinese, Chinese-American, and Anglo-American mothers. International Journal of Psychology, 22, 409-419.

Chuang, Y. C. (1998). The cognitive structure of role norms in Taiwan. Asian Journal of Social Psychology, 1, 239-251.

Cooke, R.A., \& Rousseau, D.M. (1988). Behavioral norms and expectations: A quantitative approach to the assessment of culture. Group \& Organization Studies, 13(3), 245-273.

Cooke, R.A.., \& Szumal, J.L. (1993). Measuring normative beliefs and shared behavioral expectations in organizations: The reliability and validity of the organizational culture inventory. Psychological Reports, 72, 1299-1330. 
Cox, T.H., Lobel, S.A., \& Mc Leod, P.L. (1991). Effects of ethnic group cultural differences on cooperative and competitive behavior on a group task. Academy of Management Journal, 34, 827-847.

Crossland, C., \& Hambrick, D.C. (2005). How national systems influence executive discretion: A study of CEO effects in three countries. Working paper. The Pennsylvania State University.

Crowe, E., \& Higgins, E.T. (1997). Regulatory focus and strategic inclinations: Promotion and prevention in decision making. Organizational Behavior and Human Decision Processes, 69, 117-132.

Cummings, L.L., \& Anton, R.J. (1990). The logical and appreciative dimensions of accountability. In S. Sivastva, D.C. Cooperrider, \& Associates (Eds.), Appreciative management and leadership. San Francisco: Jossey-Bass.

Dahlgaard, J.J., Kristensen, K., Kanji, G.K., Juhl, H.J., \& Sohal, A.S. (1998). Quality management practices: A comparative study between East and West. International Journal of Quality and Reliability Management, 15, 812-826.

Dastmalchian, A., Lee, S., \& Ng, I. (2000). The interplay between organizational and national cultures: A comparison of organizational practices in Canada and South Korea using the Competing Values Framework. International Journal of Human Resource Management, $11,388-412$.

Dawson, J. L. M. (1967a). Cultural and physiological influences on spatial-perceptual processes

in West Africa-Part I. International Journal of Psychology, 2, 115-128.

Dawson, J. L. M. (1967b). Cultural and physiological influences on spatial-perceptual processes

n West Africa-Part II. International Journal of Psychology, 2, 171-185.

Delery, J.E. (1998). Issues of fit in strategic human resource management: Implications for research. Human Resource Management Review, 8, 289-310.

DiMaggio, P.J., \& Powell, W.W. (1991). The iron cage revisited: Institutional isomorphism and collective rationality in organizational fields. In W.W. Powell and P.J. DiMaggio (Eds.), The new institutionalism in organizational analysis (pp. 63-82). Chicago: University of Chicago Press.

Durkheim, E. (1964). The division of labor in society, trans. New York: The Free Press, 1964. Originally published in 1893, Paris: Alcan.

Earley, P. C. (1993). East meets West meets Mideast: Further explorations of collectivistic and individualistic work groups. Academy of Management Journal, 36, 319-348.

Earley, P.C. \& Mosakowski, E. (2002). Linking culture and behavior in organizations: Suggestions for theory development and research methodology. In F. Dansereau \& F. J. Yammarino (Eds.) Research in multi-level issues volume 1: The many faces of multilevel issues (pp.279-319). San Francisco: Elsevier Science.

Elenkov, D. S., \& Manev, I. M. (2005). Top management leadership and influence on innovation: The role of sociocultural context. Journal of Management, 31, 381-402.

Emery, F.E., \& Trist, E.L. (1965). The causal texture of organizational environments. Human Relations, 18, 21-32.

Erez, M., \& Earley, P.C. (1987). Comparative analysis of goal-setting strategies across cultures. Journal of Applied Psychology, 72, 658-665.

Erez, M., \& Earley, P. C. (1993). Culture, self-identity, and work. New York: Oxford University Press.

Fishbein, M. \& Ajzen, I. (1975). Belief, attitude, intention, and behavior: An introduction to theory and research. Reading, MA: Addision-Wesley.

Fiske, A., Kitayama, S., Markus, H., \& Nisbett, R. (1998). The cultural matrix of social psychology. In D. T. Gilbert \& S. T. Fiske (Eds.) The Handbook of social psychology (Vol. 2, $4^{\text {th }}$ ed., pp. 915-981). New York, NY: McGraw-Hill. 
Fliaster, A. (2001). Deployment of knowledge workers in Japanese R\&D at the turning point towards the knowledge-based economy. In J. B. Kidd, X. Li, \& F-J. Richter (Eds.) Advances in human resource management in Asia (pp. 42-60). New York: Palgrave.

Friedman, R.S., \& Förster, J. (2001). The effects of promotion and prevention cues on creativity. Journal of Personality and Social Psychology, 81, 1001-1013.

Frink, D.D. \& Klimoski, R.J. (1998). Toward a theory of accountability in organizations and human resources management. Research in Personnel and Human Resources Management, 16, 1-51.

Frink, D. D. \& Klimoski, R. J. (2004). Advancing accountability theory and practice: Introduction to the Human Resources Management Review Special Edition. Human Resource Management Review.

Fujiwara, M. (1993). Hiring and staffing. In M. Tsuda (Ed.) Personnel management (pp. 107120). Tokyo: Minerva Publishing.

Gabreyna, W. (1999). Psychological anthropology and the 'levels of analysis' problem: We married the wrong cousins. In J. C. Lasry, J. Adair, \& K. Dion (Eds.) Latest contributions to cross-cultural psychology (pp. 333-351). Lisse: Swets \& Zeitlinger.

Gelfand, M. J. (1999). Cultural tightness-looseness: A multilevel investigation. National Science Foundation Grant \#\#9910760

Gelfand, M. J., \& Brett, J. M. (Eds.) (2004). The handbook of negotiation and culture. Palo Alto, CA: Stanford University Press.

Gelfand, M.J., Nishii, L.H, Chan, D. K-S., Yamaguchi, S., \& Triandis, H.C. (1998). Toward a theory of tightness-looseness: Further empirical evidence from the U.S. and Japan. Paper Presented at the $25^{\text {th }}$ Annual Conference of the International Association of Cross-Cultural Psychology.

George, J.M., \& Zhou, J. (2001). When openness to experience and conscientiousness are related to creative behavior: An interactional approach. Journal of Applied Psychology, $86,513-524$.

Geringer, J.M. \& Herbert, L. (1991). Measuring performance of international joint ventures. Journal of International Business Studies, 22(2), 249-264.

Gonzalez-Roma, V., Peiro, J.M., \& Tordera, N. (2002). An examination of the antecedents and moderator influences of climate strength. Journal of Applied Psychology, 87, 465-473.

Gordon, G.G. (1991). Industry determinants of organizational culture. Academy of Management Review, 16, 396-415.

Halloway, S.D. (1999). Divergent cultural models of child rearing and pedagogy in Japanese preschools. New directions for child and adolescent development, 83-Spring, 61-75.

Hambrick, D.C., \& Mason, P.A. (1984). Upper echelons: The organization as a reflection of its top managers. Academy of Management Review, 9, 193-206.

Hamilton, G.G., \& Biggart, N.W. (1988). Market, culture, and authority: A comparative analysis of management and organization in the far East. American Journal of Sociology, 94, S52-S94.

Hanks, S.H., Watson, C.J., Jansen, E., \& Chandler, G.N. (1993). Tightening the life-cycle construct: A taxonomic study of growth stage configurations in high-technology organizations. Entrepreneurship Theory and Practice, Winter, 5-29.

Herbig, P., \& Dunphy, S. (1998). Culture and innovation. Cross-Cultural Management, 5 (4), 1321.

Higgins, E.T. (1996). The "self digest": Self-knowledge serving self-regulatory functions. Journal of Personality and Social Psychology, 71, 1062-1083.

Higgins, E. T., Friedman, R. S., \& Harlow, R. E. (2001). Achievement orientations from subjective histories of success. Promotion pride versus prevention pride. European Journal of Social Psychology, 31, 3-23. 
Higgins, E.T., Shah, J., \& Friedman, R. (1997). Emotional responses to goal attainment: Strength of regulatory focus as moderator. Journal of Personality and Social Psychology, $72,515-525$.

Holzer, S. (2000). Schedule in Japan. AnimaniA, March/April, 72-75.

Ho, D.Y.F. (1981). Traditional patterns of socialization in Chinese society. Acta Psychologica Taiwanica, 23, 81-95.

Hofstede, G. (1980). Culture's consequences. Beverly Hills, CA: Sage.

Hofstede, G., Neuijen, B., Ohayv, D., \& Sanders, G. (1990). Measuring organizational cultures: A qualitative and quantitative study across twenty cases. Administrative Science Quarterly, 35, 286-316.

Hopwood, D. (1988). Syria 1945-1986: Politics and society. London: Unwin Hyman Ltd.

House, R. J., Hanges, P.J. Javidan, M., Dorfman, P.W., \& Gupta, V. (2004). Culture, leadership, and organizations: The GLOBE study of 62 cultures. San Francisco: Sage Publications.

House, R.J, Rousseau, D. M., \& Thomas-Hunt, M. (1995). The meso paradigm: A framework for the integration of micro and macro organizational behavior. In L. L. Cummings \& B. M. Staw (Eds.), Research in organizational behavior (Vol. 17, pp. 71-114). Greenwich, CT: JAI Press.

Hupp, S.C., Lam, S. F., \& Jaeger, J. (1992). Differences in exploration of toys by one-year old children: A Korean and American comparison. Behavior Science Research, 26, 123-135.

Inglehart, R., Basañez, M., \& Moreno, A. (1998). Human values and beliefs: A cross-cultural sourcebook. Ann Arbor, MI: University of Michigan Press.

Ip, G.W.M. \& Bond, M. H. (1995). Culture, values, and the spontaneous self-concept. Asian Journal of Psychology, 1, 30-36.

Jackson, J. (1966). A conceptual and measurement model for norms and roles. Pacific Sociological Review, Spring.

Jennings, P.D., Cyr, D., \& Moore, L.F. (1995). Human resource management on the Pacific Rim: An integration. In L.F. Moore \& P.D. Jennings (Eds.) Human resource management on the pacific rim: Institutions, practices, and attitudes. (pp. 351-379), New York: de Gruyter.

Jepperson, R.L., \& Meyer, J.W. (1991). The public order and the construction of formal organizations. In W.W. Powell \& P.J. DiMaggio (Eds.), The new institutionalism in organizational analysis (pp. 204-231). Chicago: University of Chicago Press.

Jones, G.K., \& Davis, H.J. (2000). National culture and innovation: Implications for locating global R\&D operations. Management International Review, 40, 11-39.

Judge, T.A., Thoresen, C.J., Pucik, V., \& Welbourne, T.M. (1999). Managerial coping with organizational change: A dispositional perspective. Journal of Applied Psychology, 84, 107-122

Kanfer, R. (1990). Motivation theory and industrial and organizational psychology. In M.D. Dunnette \& L. M. Hough (Eds.) Handbook of industrial and organizational psychology (Vol. 1, pp. 75-170). Consulting Psychologists Press, Inc: Palo Alto, CA.

Kanungo, R.N., \& Jaeger, A.M. (1990). Introduction: The need for indigenous management in developing countries. In A.M. Jaeger \& R.N. Kanungo (Eds), Management in developing countries (pp. 1-19). London: Routledge

Katz, S.M., Casey, R., \& Aiman-Smith, L. (2005). Optimizing ROI of time-to-market practices. Research Technology Management, 48, 47-57.

Katz, D., \& Kahn, R.L. (1978). The social psychology of organizations (2 ${ }^{\text {nd }}$ ed.). New York: Wiley.

Kidder, L.H. (1992) Requirements for being Japanese: Stories of returnees. International Journal of Intercultural Relations, 16, 383-393.

Kim, S.J. (1987). Labor and employment. In A. Whitehill (Ed.) Doing business in Korea. London: Croom, Helm. 
Kirton, M. (1976). Adaptors and innovators: A description and measure. Journal of Applied Psychology, 61, 622-629.

Kirton, M., \& Bailey, A. (1991). Adaptors and innovators: Preference for educational procedures. Journal of Psychology: Interdisciplinary and Applied, 125, 445-466.

Klein, R.L., Bigley, G.A., \& Roberts, K.H. (1995). Organizational culture in high reliability organizations: An extension. Human Relations, 7, 771-793.

Kobayashi, E. (1998). A cross-cultural study of noncompliant behaviors in Japanese and United States hospitals: Noncompliance as a response to perceived threats of shame, embarrassment, and management sanctions. Dissertation Abstracts International: Section B: The Sciences \& Engineering, Vol. 58(9-B), pp.5193.

Kozlowski, S.W.J., \& Klein, K.J. (2000). A multilevel approach to theory and research in organizations: Contextual, temporal, and emergent processes. In S.W.J. Kozlowski \& K.J. Klein (Eds.), Multilevel theory, research, and methods in organizations:

Foundations, extensions, and new directions (pp. 3-90). San Francisco, CA: JosseyBass.

Kristof-Brown, A.L., Jansen, K.J., \& Colbert, A.E. (2002). A policy capturing study of the simultaneous effects of fit with jobs, groups, and organizations. Journal of Applied Psychology, 87, 985-993.

Kurland, N.B. \& Egan, T.D. (1999). Public v. private perceptions of formalization, outcomes, and justice. Journal of Public Administration Research and Theory, 9, 437-458.

Lerner, J.S., \& Tetlock, P.E. (1999). Accounting for the effects of accountability. Psychological Bulletin, 125, 255-275.

Levine, J.M., Higgins, E.T., \& Choi, H.S. (2000). Development of strategic norms in groups. Organizational Behavior and Human Decision Processes, 82, 88-101.

Leung, K., Bond, M.H., de Carrasquel, S.R. Munoz, C., Hernandez, M., et al. (2002). Social axioms: The search for universal dimensions of general beliefs about how the world functions. Journal of Cross-Cultural Psychology, 33, 286-302.

Leung, K., Bond, M.H., \& Schwartz, S.H. (1995). How to explain cross-cultural differences: Values, valences, and expectations? Asian Journal of Psychology, 1, 70-75.

Leymann, H. (1996). The content and development of mobbing at work. European Journal of Work and Organizational Psychology, 5, 165-184.

Lieberman, N., Idson, L.C., Camacho, C.J., \& Higgins, E.T. (1999). Promotion and prevention choices between stability and change. Journal of Personality and Social Psychology, 77, 1135-1145.

Lincoln, J.R., Hanada, M., \& Olson, J. (1981). Cultural orientations and individual reactions to organizations: A study of employees of Japanese-owned firms. Administrative Science Quarterly, 26, 93-115.

Lincoln, J.R., \& Kalleberg, A.L. (1985). Work organization and workforce commitment: A study of plants and employees in the U.S. and Japan. American Sociological Review, 50, 738760.

Lindell, M.K., \& Brandt, C.J. (2000). Climate quality and climate consensus as mediators of the relationship between organizational antecedents and outcomes. Journal of Applied Psychology, 85, 331-348.

Litwin, G.H., \& Stringer, R.A. (1968). Motivation and organizational climate. Boston: Harvard Business School Press.

Lu, Y. \& Bjorkman, I. (1997). HRM practices in China-Western joint ventures: MNC standardization versus localization. International Journal of Human Resource Management, 8(5), 614-628.

Magnier, M. (1999). Japanese firms use bullying to thin their ranks. Los Angeles Times, Saturday, July 24. 
Malamaut, A.B. (2002). Socialization and perceptual agreement: Testing a bottom-up emergence model of organizational climate formation. Dissertation Abstracts International: Section B: The Sciences and Engineering, 63, 1598.

Marsden, P.V., Cook, C.R., \& Knoke, D. (1994). Measuring organizational structures and environments. American Behavioral Scientist, 37, 891-910.

Martin, K. \& Freeman, R.E. (2003). Some problems with employee monitoring. Journal of Business Ethics, 43, 353-361.

McAuley, P.C., Bond, M. H., \& Kashima, E. (2002). Toward defining situations objectively: A culture-level analysis of role dyads in Hong Kong and Australia. Journal of CrossCultural Psychology, 33, 363-379.

McKelvey, B. (1982). Organizational systematics: Taxonomy, classification, and evolution. Los Angeles:University of California Press.

Mellahi, K., \& Wood, G.T. (2001). Human resource management in Saudi Arabia. In P.S. Budhwar \& Y.A. Debrah (Eds) Human Resource Management in Developing Countries (pp. 135-152). New York: Routledge Press.

Merton, R.K. (1968). Social theory and social structure. New York: Free Press.

Milliken, F.J., \& Martins, L.L. (1996). Searching for common threads: Understanding the multiple effects of diversity in organizational groups. Academy of Management Review, 21, 402-433.

Mischel, W. (1977). The interaction of person and situation. E. Magnusson \& N.S. Endler (Eds.), Personality at the crossroads. Hillsdale, NJ: Erlbaum.

Morishima, M. (1995). The Japanese human resource management system: A learning bureaucracy. In L.F. Moore\& P.D. Jennings (Eds.) Human resource management on the Pacific Rim: Institutions, practices, and attitudes (pp. 119-150), New York: de Gruyter.

Morris, M.W., Podolny, J.M., \& Ariel, S. (2000). Missing relations: Incorporating relational constructs into models of culture. In P. C. Earley \& H. Singh (Eds.), Innovations in international and cross-cultural management (pp. 52-90). Thousand Oaks, CA: Sage.

Morris, M.W., Williams, K.Y., Leung, K., Larrick, R., \& Mendoza, M.T., et al. (1998). Conflict management style: Accounting for cross-national differences. Journal of International Business Studies, 29, 729-747.

Moskowitz, G.B. (1993). Individual differences in social categorization: The influence of personal need for structure on spontaneous trait inferences. Journal of Personality and Social Psychology, 65, 132-142.

Mowday, R.T., \& Sutton, R.I. (1993). Organizational Behavior: Linking individuals and groups to organizational contexts. Annual Review of Psychology, 44, 195-229.

Namie, G., \& Namie, R. (2000). The bully at work: What you can do to stop the hurt and reclaim your dignity on the job. Naperville, IL: Sourcebooks.

Naveh, E., \& Erez, M. (2004). Innovation and attention to detail in the quality improvement paradigm. Management Science, 50, 1576-1586.

Neuberg, S.L., \& Newsom, J.T. (1993). Personal need for structure: Individual differences the desire for simple structure. Journal of Personality and Social Psychology, 65, 113-131.

Nishii, L.H., \& Wright, P.M. (in press). Variability within organizations: Implications for strategic human resource management. In D.B. Smith (Ed.), The people make the place: Festschrift in honor of Benjamin Schneider. New York: Lawrence Erlbaum

O'Reilly, C.A., \& Chatman, J.A. (1996). Culture as social control: Corporations, cults, and commitment. Research in Organizational Behavior, 18, 157-200.

O'Reilly, C.A., Chatman, J. \& Caldwell, D.F. (1991). People and organizational culture: A profile comparison approach to assessing person-organization fit, Academy of Management Journal, 14, 487-516.

Olson, P.D., \& Terpstra, D.E. (1992). Organizational structural changes: Life-cycle stage influences and managers' and interventionists' challenges. Journal of Organizational Change, 5, 27-40. 
Orru, M., Biggart, N.W., \& Hamilton, G.G. (1991). Organizational isomorphism in East Asia. In W.W. Powell and P.J. DiMaggio (Eds.), The new institutionalism in organizational analysis (pp. 361-389). Chicago: University of Chicago Press.

Ostroff, C., \& Bowen, D.E. (2000). Moving HR to a higher level: HR practices and organizational effectiveness. In K.J. Klein \& S.W.J. Kozlowski (Eds.), Multilevel theory, research, and methods in organizations: Foundations, extension, and new directions (211-266). San Francisco, CA: Jossey-Bass Inc.

Ostroff, C., Shin, Y., and Kinicki, A. J. (2005). Multiple perspectives of congruence: Relationships between value congruence and employee attitudes. Journal of Organizational Behavior, 26, 591-623.

Pan, Y. (2002). Equity ownership in international joint ventures: The impact of source country factors. Journal of International Business Studies, 33(2), 375-384.

Parboteeah, K.P., \& Cullen, J.B. (2003). Social institutions and work centrality: Explorations beyond national culture. Organization Science, 14, 137-148.

Parkes, C. (2001). Singapore. Emeryville, CA: Avalon Travel Publishing.

Pearson, R.P. (1984). Behavior and morality. In L.E. Clark (Ed.), Through Middle Eastern eyes (pp. 42-49). New York: The Center for International Training and Education.

Pelto, P. (1968). The difference between 'tight' and 'loose' societies. Transaction, 5, 37-40.

Peterson, K.D. (1984). Mechanisms of administrative control over managers in educational organizations. Administrative Science Quarterly, 29, 573-597.

Price, R.H., \& Bouffard, D.L. (1974). Behavioral appropriateness and situational constraint as dimensions of social behavior. Journal of Personality and Social Psychology, 30, 579586.

Quinn, R.E. (1988). Beyond rational management: Mastering the paradoxes and competing demands of high performance. San Francisco: Jossey-Bass.

Ramakrishnan, M. (1988). Effects of anxiety and scarcity of resources on kiasu behavior. Academic exercise. Singapore: National University of Singapore.

Redding, S.G., Norman, A., \& Schlander, A. (1994). The nature of individual attachment to the organization: A review of East Asian variations. In H.C. Triandis, \& M.D. Dunnette (Eds.), Handbook of industrial and organizational psychology, Vol. 4 (2 ${ }^{\text {nd }}$ ed., pp.647-688).

Ricardo, D. (1817). On the principles of political economy and taxation. London: Murray.

Rios-Ellis, B., Bellamy, L., \& Shoji, J. (2000). An examination of specific types of ijime within Japanese schools. School Psychology International, 21, 227-241.

Rohner, R. (1984). Toward a conception of culture for cross-cultural psychology. Journal of Cross-Cultural Psychology, 23, 214-27.

Rousseau, D.M. (1990). Assessing organizational culture: The case for multiple methods. In B. Schneider (Ed.), Organizational climate and culture (pp. 153-192). San Francisco: Jossey-Bass.

Rosenzweig, P.M., \& Nohria, N. (1994). Influences on human resource management practices in multinational corporations. Journal of International Business Studies, 25(2), 229-251.

Rozelle, R.M., \& Baxter, J.C. (1981). Influence of role pressures on the perceiver: Judgments of videotaped interviews varying judge accountability and responsibility. Journal of Applied Psychology, 66, 437-441.

Rucker, D., Polifroni, M., Tetlock, P.E., \& Scott. A.L. (2004). On the assignment of punishment: The impact of general-societal threat and the moderating role of severity. Personality and Social Psychology, 30, 673-684.

Ruiz, F., \& Tanaka, K. (2001). The ijime phenomenon and Japan: Overarching considerations for cross-cultural studies. Psychologia, 44, 128-138.

Ryback, D., Sanders, A.L., Lorentz, J., \& Koestenblatt, M. (1980). Child-rearing practices reported by students in six cultures. The Journal of Social Psychology, 110, 153-162. 
Rybowiak, V., Garst, H., Frese, M., \& Batinic, B. (1999). Error orientation questionnaire (EOQ): Reliability, validity, and different language equivalence. Journal of Organiztaional Behavior, 20, 527-547.

Scarr, S. (1993). Biological and cultural diversity: The legacy of Darwin for development. Child Development, 64, 1333-1353.

Schneider, B. (1987). The people make the place. Personnel Psychology, 40, 437-453.

Schneider, B. (2001). Fits about fit. Applied Psychology: An International Review, 50, 141-152.

Schneider, B., Goldstein, H.W. \& Smith, D.B. (1995). The ASA Framework: An update. Personnel Psychology, 48, 747-779.

Schneider, B., Salvaggio, A.N., \& Subirats, M. (2002). Climate strength: A new direction for climate research. Journal of Applied Psychology, 87, 220-229.

Schneider, B., Smith, D.B., Taylor, S., \& Fleenor, J. 1998. Personality and organizations: A test of the homogeneity of personality hypothesis. Journal of Applied Psychology, 83, 462470.

Schvaneveldt, R.W. (1990). Proximities, networks, and schemata. In R.W. Schvaneveldt (Ed.), Pathfinder associative networks: Studies in knowledge organization (pp.135-148). Norwood, NJ: Ablex.

Schwartz, S.H. (1994). Beyond individualism/collectivism: New cultural dimensions of values. In U. Kim, H.C. Triandis, C. Kagitiçibasi, S. Choi, \& G. Yoon (Eds.), Individualism and collectivism: Theory, method, and applications. Thousand Oaks, CA: Sage.

Schwartz, S., \& Sagie, G. (2000). Value consensus and importance: A cross-national study. Journal of Cross-Cultural Psychology, 31, 465-497.

Seeley, E.A., \& Gardner, W.L. (2003). The "self-less" and self-regulation: The role of chronic other-orientation in averting self-regulatory depletion. Self and Identity, 22, 103-117.

Shane, S.A. (1992). Why do some societies invent more than others? Journal of Business Venturing, 7, 29-46.

Shenon, P. (1994). Singapore carries out the caning of a U.S. teenager. New York Times, Friday, May 6.

Silverblatt, A. (2004). Media as social institution. American Behavioral Scientist, 48(1), 35-41.

Smith, A. (1776). An inquiry into the nature and causes of the wealth of nations. London: Methuen and Co., Ltd.

Smith, P.B., \& Schwartz, S.H. (1997). Values. In J. W. Berry, Y. H. Poortinga, \& J. Pandy (Eds.) Handbook of cross-cultural psychology ( ${ }^{\text {nd }}$ ed., Vol.3, pp. 77-118). Needham Heights, MA: Allyn \& Bacon.

Sohal, A.S. (1998). Assessing manufacturing/quality culture and practices in Asian companies. International Journal of Quality and Reliability Management, 15, 920-930.

Soltani, P. (2003). Crime and punishment in Singapore. Pacific Rim Magazine. From http://www.langara.bc.ca/prm/2003/singapore.html

Sorenson, J.B. (2002). The strength of corporate culture and reliability of firm performance. Administrative Science Quarterly, 47, 70-91.

Souza-Poza, A., Nystrom, H., \& Wiebe, H. (2000). A cross-cultural study of the different effects of corporate culture on TQM in three countries. International Journal of Quality and Reliability Management, 18, 744-761.

Stevenson, H.W., \& Stigler, J.W. (1992). The learning gap: Why our schools are failing and what we can learn from Japanese and Chinese education. New York, NY: Summit Books.

Strauss, C., \& Quinn, N. (1997). A cognitive theory of cultural meaning. Cambridge: Cambridge University Press.

Sussman, L. \& Karlekar, K.D. (2002). The annual survey of press freedom 2002. New York, NY: Freedom House.

Sutton, R.I., \& Galunic, D.C. (1996). Consequences of public scrutiny for leaders and their organizations. In B.M. Staw \& L.L. Cummings (Eds.), Research in organizational 
behavior: An annual series of analytical essays and critical reviews, (vol. 18, pp. 201250). US: Elsevier Science/JAI Press.

Takemura, K., \& Takagi, O. (1988). Psychological factors in the "ijime" phenomenon: Negative attitude toward a deviator and conformity toward a majority. Japanese Journal of Educational Psychology, 36, 57-62.

Tayeb, M. (2001). Human resource management in Iran. In P.S. Budhwar \& Y.A. Debrah (Eds) Human resource management in developing countries (pp. 121-134). New York: Routledge Press.

Tetlock, P.E. (1985). Accountability: The neglected social context of judgment and choice. In L. L. Cummings \& B. M. Staw (Eds.), Research in organizational behavior (Vol. 7, pp. 297332). Greenwich, CT: JAI Press.

Tetlock, P.E. (1992). The impact of accountability on judgment and choice: Toward a social contingency model. Advances in Experimental Social Psychology, 25, 331-376.

Tetlock, P.E., (2002). Social functionalist frameworks for judgment and choice: Intuitive politicians, theologians, and prosecutors. Psychological Review, 109, 451-471.

Tetlock, P.E., Skitka, L., \& Boettger, R. (1989). Social and cognitive strategies for coping with accountability: Conformity, complexity, and bolstering. Journal of Personality and Social Psychology, 57, 632-640.

Tinsley, C. (1998). Models of conflict resolution in Japanese, German, and American cultures. Journal of Applied Psychology, 83, 316-323.

Triandis, H.C. (1972). The analysis of subjective culture. New York: John Wiley.

Triandis, H.C. (1989). The self and social behavior in differing cultural contexts. Psychological Review, 96, 506-520.

Triandis, H.C. (1994). Culture and social behavior. New York: McGraw-Hill.

United Nations Office on Drugs and Crime. (2004). UNODC - The Seventh United Nations Survey on Crime Trends. http://www.unodc.org/unodc/en/crime cicp survey seventh.htm|\#responses

Verberg, R.M., Drenth, P.J.D., Koopman, P.L., van Muijen, J.J., \& Wang, Z.M. (1999). Managing human resources across cultures: A comparative analysis of practices in industrial enterprises in China and the Netherlands. The International Journal of Human Resource Management, 10, 391-410.

Wächter, H. \& Stengelhofen, T. (1995). Germany. In. I. Brunstein (Ed.) Human resource management in Western Europe (pp.89-112). Berlin, Germany: Walter de Gruyter.

Wiersema, M.F., \& Bird, A. (1993). Organizational demography in Japanese firms: Group heterogeneity, individual dissimilarity, and top management team turnover. Academy of Management Journal, 36, 996-1025.

Wilkins, A.L., \& Ouchi, W.G. (1983). Efficient cultures: Exploring the relationship between culture and organizational performance. Administrative Science Quarterly, 28, 468-481.

Withers, B.E., \& Ebrahimpour, M. (1996). An examination of ISO 9000 registration practices if American, German and Japanese firms operating in the USA. The International Journal of Quality and Reliability, 13, 8-16.

Witkin, H.A., \& Berry, J.W. (1975). Psychological differentiation in cross-cultural perspective. Journal of Cross-cultural Psychology, 6, 4-87.

Wong, V. (2002). Antecedents of international new product rollout timeliness. International Marketing Review, 19, 120-132.

Wright, P.M., \& McMahan, G.C. (1992). Theoretical perspectives for strategic human resource management. Journal of Management, 18, 295-320.

Wright, P.M. \& Snell, S.A. (1998). Toward a unifying framework for exploring fit and flexibility in strategic human resource management. Academy of Management Review, 23, 756-772.

Wu, W., \& Dai, S. (2001). A comparative study of crisis management planning in Singapore and Hong Kong. Working paper, Faculty of Business Administration, National University of Singapore. 
Zahn-Waxler, C., Friedman, R.J., Cole, P.M., Mizuta, I., \& Hiruma, N. (1996). Japanese and United States preschool children's responses to conflict and distress. Child Development, 67, 2462-2477.

Ziegert, J. C. (2002). Do women make the sorority? A Test of the attraction-selection-attrition model applied to sorority recruitment. Unpublished Masters Thesis, University of Maryland. 


\section{Footnotes}

1. Our focus on the strength of social norms and sanctioning is not the only way to characterize the external environment, but rather one important way that needs to be developed for cross-cultural research. Other approaches might focus on social roles (Chuang, 1998; McAuley, Bond, \& Kashima, 2002; Triandis, 1972), social networks (Morris et al., 2000), or aspects of the external social structure (Parboteeah \& Cullen, 2003).

2. We are currently validating such a survey measure across 35 nations for future use in studies of societal tightness-looseness. A copy of this measure can be obtained from the first author.

3. Future research may also explore the notion that organizations in tight societies can be innovative when it employees are made accountable to innovative performance. For example, in Japan, a continuous learning culture helps to afford innovation in the context of rules and bureaucracy in many organizations (Morishima, 1995). Likewise, the government in Singapore has also begun to intervene to foster more innovation within Singaporean organizations. For example, in 1997, the Prime Minister of Singapore, Goh Chok Tong, called for more creativity within schools at the $7^{\text {th }}$ International Conference on Thinking. In this respect, when innovation or change becomes a strategic goal, it may be even easier to implement in tight societies given that strong norms and enhanced coordination among individuals can facilitate faster implementation. 